\title{
Biogênese do solo
}

\section{Andreas Attila de Wolinsk Miklós ${ }^{1}$}

Resumo: O trabalho foca a dinâmica do solo sob a ação dos seres vivos na paisagem tropical. Apresenta-se a biodiversidade de todos os organismos que afetam o solo e destacam-se os impactos dos principais agentes da biogênese do solo em função da importância das densidades populacionais, das biomassas envolvidas e das ações transformadoras do meio: minhocas, térmitas, formigas e raízes de plantas são os principais atores. Ênfase especial é dada à biogênese de Latossolos e da organização espacial de stone-lines pela ação de cupins e formigas. Subsequentemente, é descrita a relação entre a biodiversidade e a renovação das terras; elemento tão essencial à vida, quanto água, ar, luz e calor. E, fechando o tema, uma síntese fenomenológica goethiana é estabelecida, propondo um funcionamento biodinâmico global da paisagem intertropical: a polaridade associação "versus" dissociação como fenômeno vital global, envolvendo a ação da água e dos seres vivos sobre o reino mineral em superfície e profundidade.

Palavras-chave: Biogênese do solo; biodiversidade; bioturbação; funcionamento biodinâmico; fenomenologia goethiana.

\section{Soil biogenesis}

Abstract: The work focuses on the dynamics of soil under the action of living beings in the tropical landscape. First, we present the biodiversity of all organisms that affect the soil and then highlight the impacts of the main agents of the soil biogenesis based on the importance of population densities, the biomass involved and the transforming actions of the environment (bioturbation): earthworms, termites, ants and plant roots are the main actors. Special emphasis is given to the biogenesis of Oxisols and spatial organization of stone-lines by the action of termites and ants. Subsequently, we report briefly the relationship between the biodiversity and the renewal of the soil. Closing the subject, a Goethean's phenomenological synthesis is established to define the biodynamic functioning of the tropical landscape: the polarity association "versus" dissociation as a vital global phenomenon involving the action of water and of living beings on the mineral kingdom, in surface and depth.

Keywords: Soil biogenesis; biodiversity; bioturbation; biodynamic functioning; Goethe's phenomenology.

\section{INTRODUÇÃO}

O manto de terra no globo terrestre tem em sua superfície a biosfera vegetal que deixa cair suas folhas devido ao processo senescente cíclico temporal. Tal camada de folhas mortas sobre o solo (serapilheira) servirá de alimento e moradia para uma infinidade de animais,

\footnotetext{
${ }^{1}$ Graduação em Agronomia pela Universidade Estadual Paulista Júlio de Mesquita Filho, MSc em Geoquímica da pela Universidade de Poitiers, França e doutorado em Ciências da Terra Especialidade Pedologia pela Universidade Paris VI. Professor da Universidade de São Paulo. E-mail: awmiklos@usp.br
} 
raízes vegetais, fungos, bactérias, actinomicetos, etc. O maior ou menor impacto no solo decorrente do comportamento ecológico (alimentar, reprodutor e construtor) da biodiversidade que afeta os solos tropicais vai definir os principais agentes da organização e dinâmica do solo, bem como, o funcionamento biodinâmico da paisagem. Para tanto, reconhecer a biodiversidade do solo é fundamental. Segundo levantamento bibliográfico e nossas pesquisas (Miklós, 1992), dentre as inúmeras espécies que habitam o solo minhocas, térmitas, saúvas e raízes de plantas são os organismos que mais impactam o solo devido à grandeza de suas populações, biomassas e ações transformadoras no meio (bioturbação). Os impactos dessa biodiversidade sobre o solo e vegetação serão objetos de caracterização. Diante desses dados é possível discernir o papel da biodiversidade e determinar o impacto dos agrossistemas biocidas $^{2}$ na renovação das terras. Finalizando, uma síntese fenomenológica goethiana do funcionamento biodinâmico de paisagens tropicais é proposta ao desvelar a polaridade processual associação "versus" dissociação, envolvendo a ação da água e dos seres vivos sobre o reino mineral em superfície (solo) e profundidade (rocha).

\section{O papel dos seres vivos na organização e dinâmica da paisagem tropical.}

\section{Biodiversidade, biomassa e bioturbação.}

Primeiro, a biodiversidade da fauna do solo; é enorme, vai do mais simples invertebrado até o mais complexo vertebrado (fig. 1 A, B e C): protozoários, asquelmintos (nematoides), moluscos, anelídeos (minhocas e enquitrídeos), artrópodes \{crustáceos (isópodes), aracnídeos (ácaros, escorpiões, aranhas), miriápodes [diplópodes: gloméris ("tatuzinho bola"), julidae ("mil patas" ou "piolho de cobra")], hexápodes (colêmbolas formigas, cupins, besouros, percevejos, dípteros, lepidópteros, etc.)\} e mamíferos (tatu), aves, répteis e anfíbios. Em seguida, a biodiversidade dos demais organismos presentes no solo, os microrganismos (microbiota), também importantes: fungos, bactérias, actinomicetos e algas $^{3}$.

A média da biomassa considerando a totalidade da fauna do solo gira em torno de 0,3 ton ha $^{-1}$. Essa biomassa é 15 vezes maior que a biomassa de humanos vivendo no planeta Terra (Bachelier, 1978).

\footnotetext{
${ }^{2}$ Sistema agrícola biocida que elimina biodiversidade e vida ao empregar produtos altamente tóxicos à vida, transgênicos e monotonizar as paisagens com as monoculturas.

${ }^{3}$ Os vírus são menos importantes.
} 


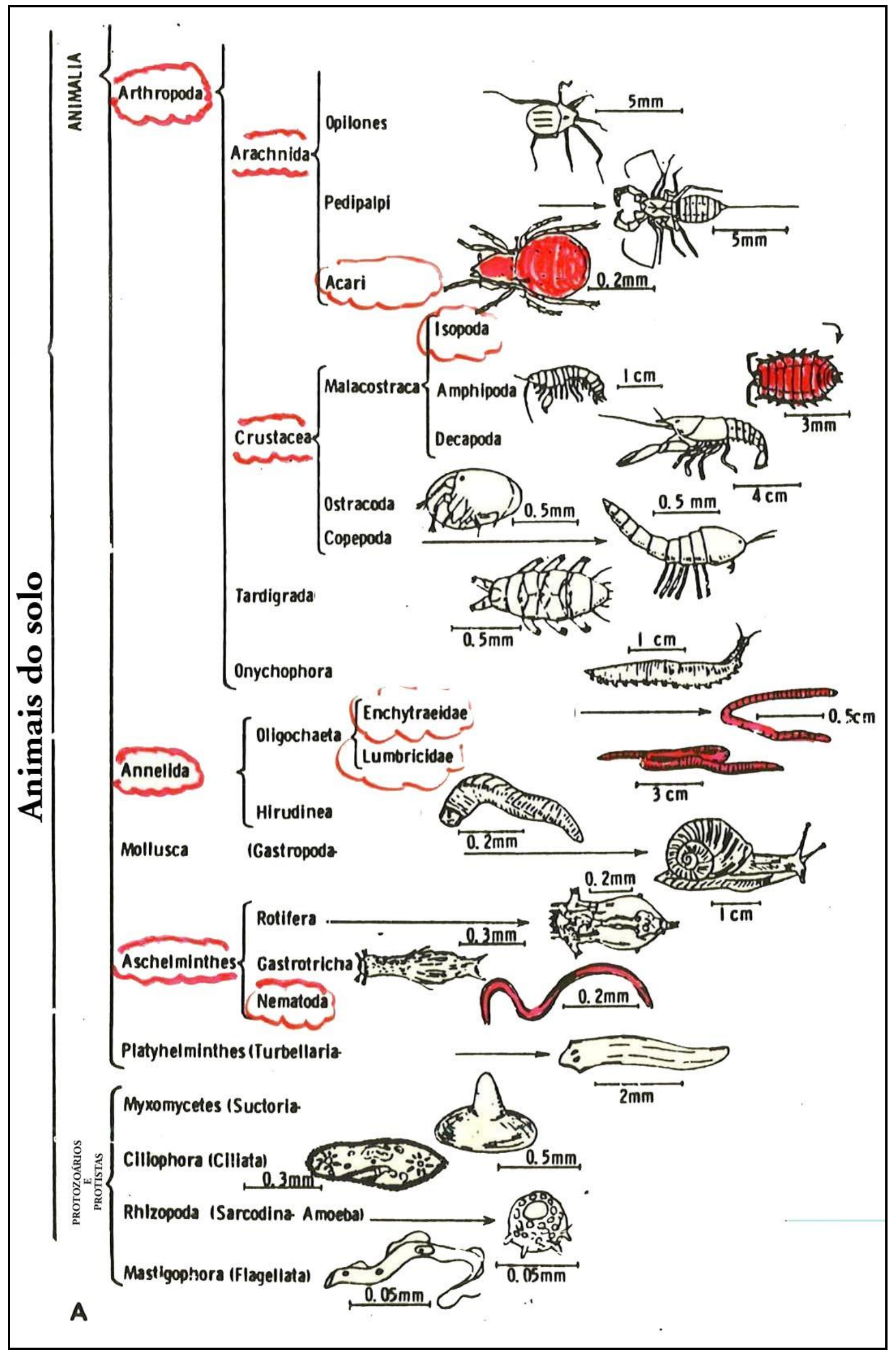


Figuras 1 A, B e C - Classificação dos animais que afetam os solos (segundo Edey, 1965; Wallwork, 1966 in Hole, 1981). Em vermelho, os que mais afetam.

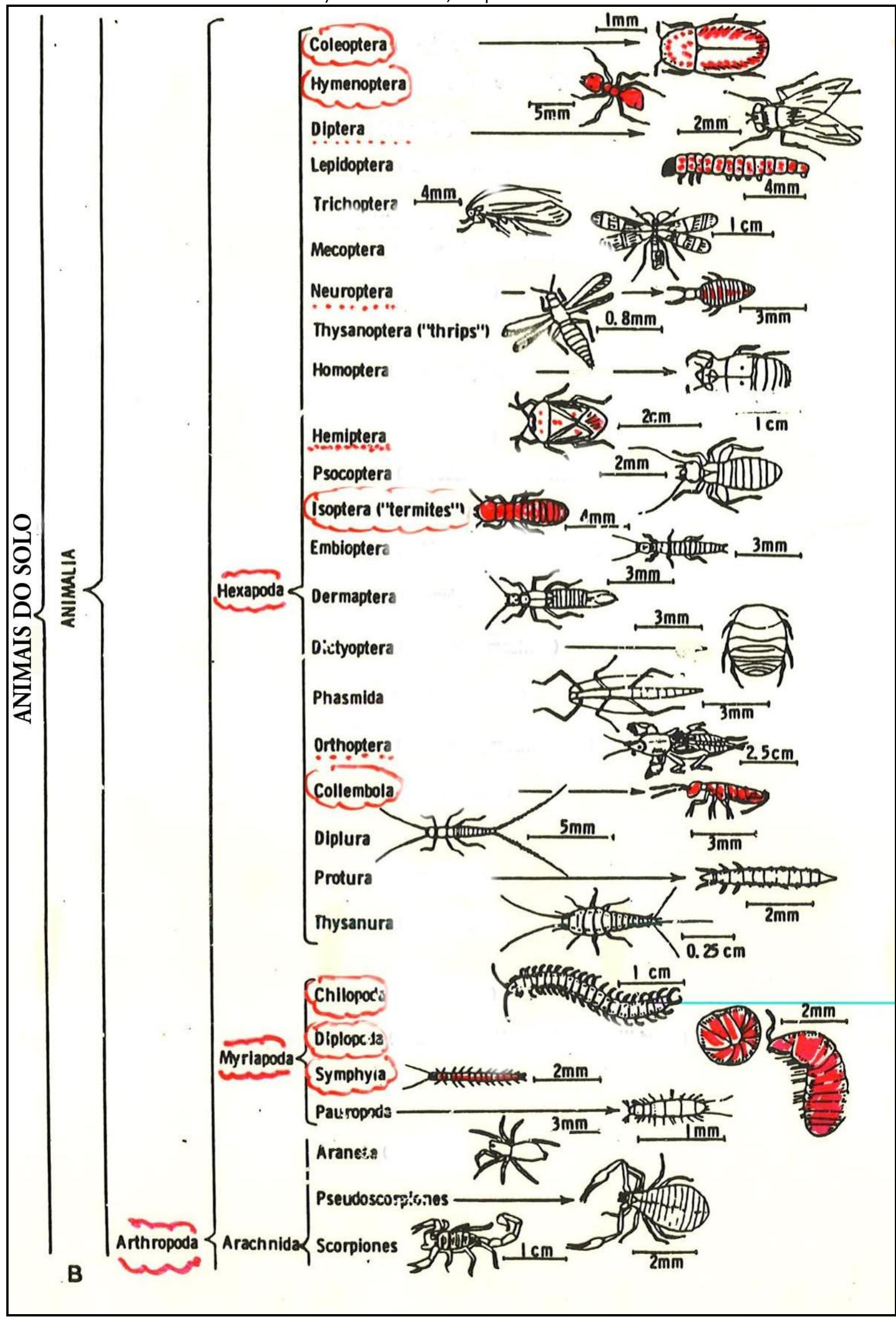

Figura 1 B. Continuação. 


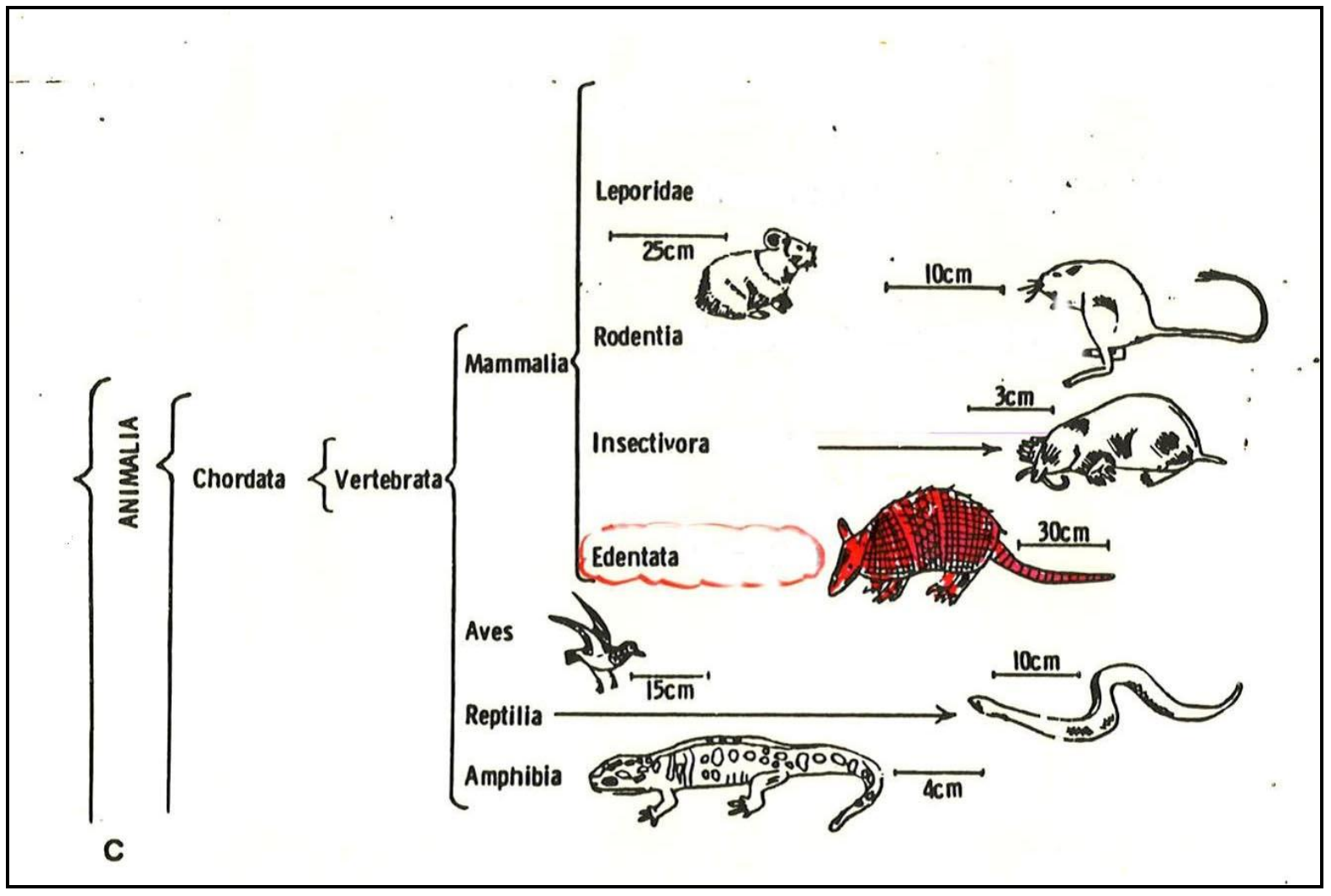

Figura 1 C. Continuação.

A estimativa média do número e da biomassa dos organismos do solo (fig. 2) apresentada abaixo se encontra em Wallwork (In Hole,1981).

Os principais tipos de vegetação recobrindo os solos intertropicais serão abordados mais adiante.

Em função da grandeza da densidade populacional, biomassa e ação transformadora do meio, minhocas, cupins, formigas e raízes vegetais configuram os principais agentes da organização e dinâmica do solo da paisagem intertropical.

As populações, biomassas e ações transformadoras no meio desses organismos serão caracterizadas a seguir. As caracterizações serão efetuadas de maneira a desvelar: (a) a importância do papel dessa biodiversidade na biogênese e biodinâmica do solo, de um lado e de outro, (b) o funcionamento biodinâmico global da paisagem tropical sob a imagem de uma síntese fenomenológica goethiana. 


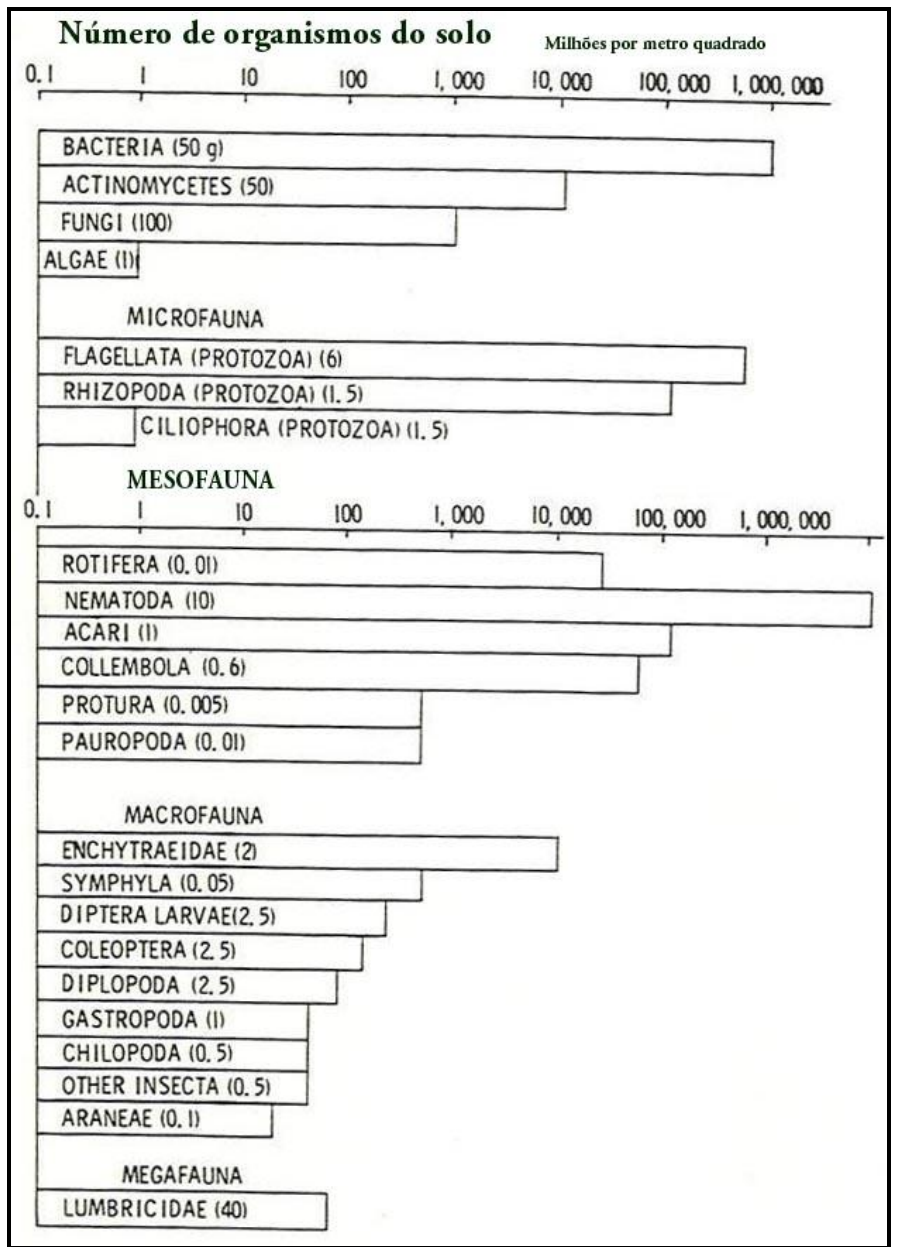

Foto 2. Estimativa representativa em número e biomassa (em parêntesis) de organismos do solo.

Minhocas (in Bachelier, 1978).

A densidade populacional das minhocas varia de 12 a 1.730 indivíduos $\mathrm{m}^{-2}$. Uma população média de 470 minhocas $\mathrm{m}^{-2}$ equivale a 4,5 ton de minhocas hidratadas ha ${ }^{-1}$ (peso vivo). 0 que equivale a 51 carneiros ha ${ }^{-1}$. Uma lotação de pasto ideal para carneiros é de 8 carneiros $\mathrm{ha}^{-1}$.

O recorde da densidade populacional de minhocas foi assinalado por Stockli (1958), num pasto da Suíça, onde encontrou uma população de 24 ton de minhocas hidratadas ha ${ }^{-1}$. Importante ressaltar o comportamento alimentar e a atividade metabólica desses animais. Raw (1962) assinalou, num pomar de macieiras do Reino Unido, que 2 a 2,5 ton de minhocas ha $^{-1}$ (peso vivo) incorpora 1,25 ton de matéria orgânica ha ${ }^{-1}$ (peso seco) em 3 a 4 meses, ou seja, $90 \%$ da serapilheira. 
O comportamento ecológico (hábitos alimentar, construtor e reprodutor) das minhocas varia conforme seu modo de vida. Diferenciam-se em minhocas epígenas, anécicas e endógenas. Minhocas epígenas vivem exclusivamente na superfície do solo, na serapilheira. No Brasil inexiste representante autóctone. A minhoca "Vermelha da Califórnia", epígena, foi importada para fins de vermicultura e produção de húmus. Pheretima havaiana é um exemplo de anécica, elas vivem nos $50 \mathrm{~cm}$ superficiais do solo e ingerem $50 \%$ de matéria orgânica (serapilheira) e 50\% de matéria mineral; são denominadas "minhoca brava", "puladeira", "incorporadora de matéria orgânica". Pontoscolex corethrurus é um exemplar endógeno, elas vivem no interior do solo, descem até um metro de profundidade quando entram em dormência, ingerem $90 \%$ de matéria mineral e $10 \%$ matéria orgânica; são denominadas de "minhoca mansa", "estruturadora". Ao ingerirem matéria mineral, as minhocas dejectam em superfície de 50 a 260 ton de solo ha ${ }^{-1}$ ano $^{-1}$.

Como elemento de comparação, considerando a densidade aparente do solo (massa volume real $^{-1}$ ) igual a 1 ton $\mathrm{m}^{-3}$, os 10 primeiros $\mathrm{cm}$ do solo tem massa igual a 1.000 ton ha ${ }^{-1}$.

Em um cerrado da Costa do Marfim, Lavelle (1975) considerando as dejeções superficiais e internas do solo de apenas uma espécie, a Millsonia $s p^{4}$, numa densidade populacional de 21 minhocas $\mathrm{m}^{-2}$, deu conta de uma ingestão de 500 ton de solo ha ${ }^{-1} \mathrm{ano}^{-1}$. Isso significa que $4 \mathrm{a}$ $5 \mathrm{~cm}$ de solo ano $^{-1}$ passam pelo trato digestivo dessa densidade populacional de minhocas.

Nesse mesmo cerrado da Costa do Marfim, Athias et al. (1975) considerando todas as espécies assinalou uma ingestão de solo de 1.000 ton ha $^{-1} \mathrm{ano}^{-1}$, ou seja, $10 \mathrm{~cm}$ de solo por ano.

Bernardes e Miklós (1994), em um Nitissolo Vermelho (Terra Roxa Estruturada) sob vegetação de Eucalipto e sub-bosque de capim gordura, em Botucatu (SP), levantaram uma densidade populacional de 250 minhocas $\mathrm{m}^{-2}\left(1.800 \mathrm{~kg} \mathrm{ha}^{-1}\right)$, sobretudo, Pontoscolex corethrurus. Introduzindo essa mesma densidade populacional em protocolo experimental, verificou-se a ingestão de 3.120 ton de solo $\mathrm{ha}^{-1} \mathrm{ano}^{-1}$. Ao transferir esses dados para o campo, poder-se-ia dizer que os $20 \mathrm{~cm}$ superficiais do solo passam pelo trato digestivo dessa densidade populacional em 10 meses. Mas, o dado é superestimado, pois não considera a estação seca da região de Botucatu, quando a atividade das minhocas cessa ( 3 a 4 meses). Seria mais seguro afirmar, em 1 a 2 anos.

\footnotetext{
${ }^{4} \mathrm{O}$ adulto atinge $15 \mathrm{~cm}$ de comprimento.
} 


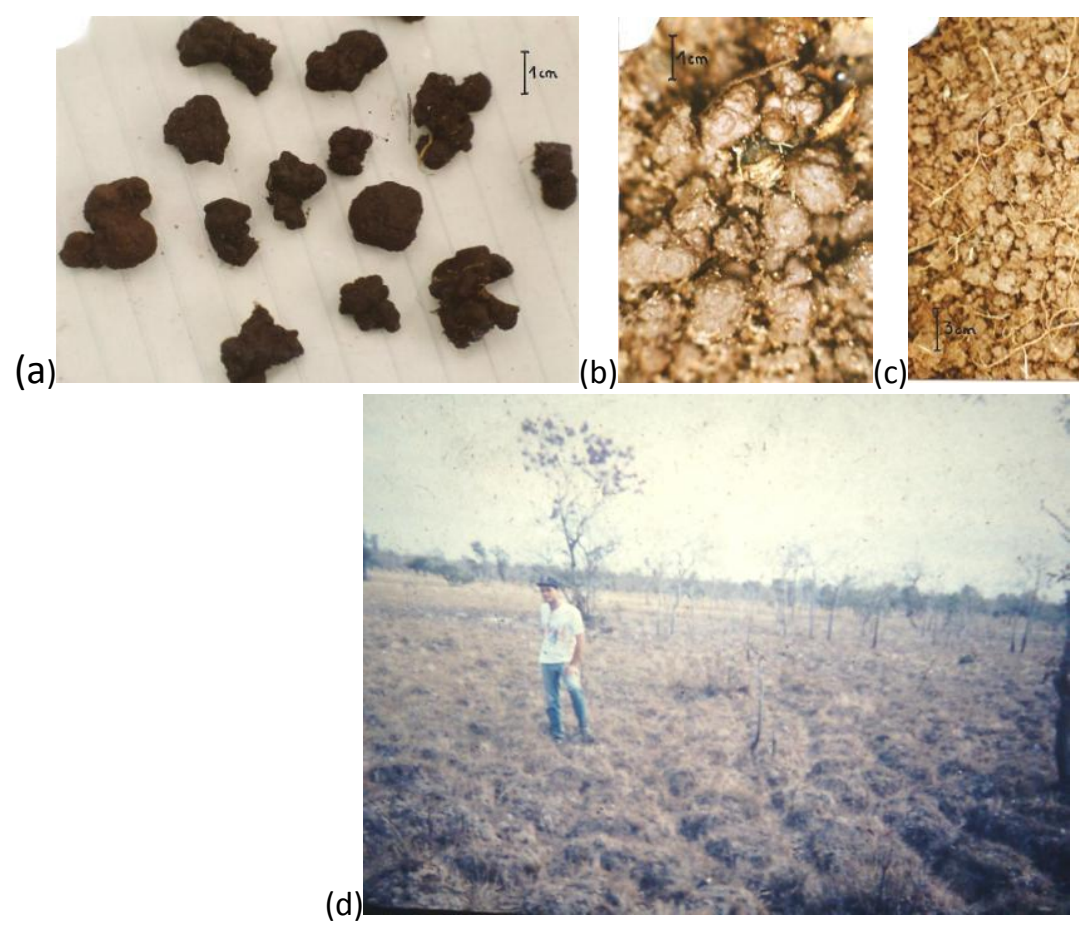

Foto 1. (a, b) Coprólitos frescos de minhocas (grumos); (c) Horizonte superficial ( $20-30 \mathrm{~cm}$ de espessura) com estrutura em grumos da Terra Roxa Estruturada, construído pelas minhocas (Miklós, 1992) e (d) Montículos de excrementos de minhocas em planícies parcialmente inundadas de Goiás. Os montículos atingem $20 \mathrm{~cm}$ de altura. [Fotos (a), (b), (c) A. A. W. Miklós, Foto (d) Ex-aluno da ESALQ / USP].

Ou seja, os 20 a $30 \mathrm{~cm}$ superficiais desse solo passam pelo trato digestivo de 250 minhocas $\mathrm{m}^{-2}$ em um a dois anos. Os grumos (foto $1 \mathrm{a}, \mathrm{b}$ ) são na realidade coprólitos de minhocas (dejeções superficiais e internas).

A foto 1 (d) ilustra montículos (murundus) de excrementos de minhocas, que se distribuem sobre dezenas de milhares de hectares em planícies inundadas de Goiás, segundo relato de ex-aluno da ESALQ, na foto.

No alto Rio Negro (Cucuí, AM), a superfície de solos em planícies inundadas dominadas por Espodossolos Cárbicos hidromórficos (Podzóis hidromórficos) é repleta de montículos resultantes da dejeção de minhocas (foto 2a, b e c) (Mafra et al., 2007). Os montículos podem atingir mais de $40 \mathrm{~cm}$ de altura (foto $2 \mathrm{~b}$ ) e têm a mesma composição que o horizonte superficial organomineral de 20 a $30 \mathrm{~cm}$ de espessura (foto 3a). Essa camada superficial resulta do desmantelamento e aplainamento dos montículos constituídos de excrementos das minhocas. Esses espécimes são muito grandes e podem chegar até 1 metro de comprimento (foto $2 \mathrm{c}$ ). A vegetação é constituída pela floresta densa úmida sempervirente (floresta equatorial) e a serapilheira é formada por uma fina camada de folhas frescas, mais ou menos fragmentadas, recentemente caídas ao solo. Destarte, poder-se-ia arriscar a afirmar que as minhocas ingeririam, decomporiam e incorporariam o aporte anual de folhas 
da floreta equatorial, o equivalente a 16 ton ha ${ }^{-1} \mathrm{ano}^{-1}$, peso seco (Boissezon et al., 1973).

Conclusões importantes se sobreporiam:

(a)
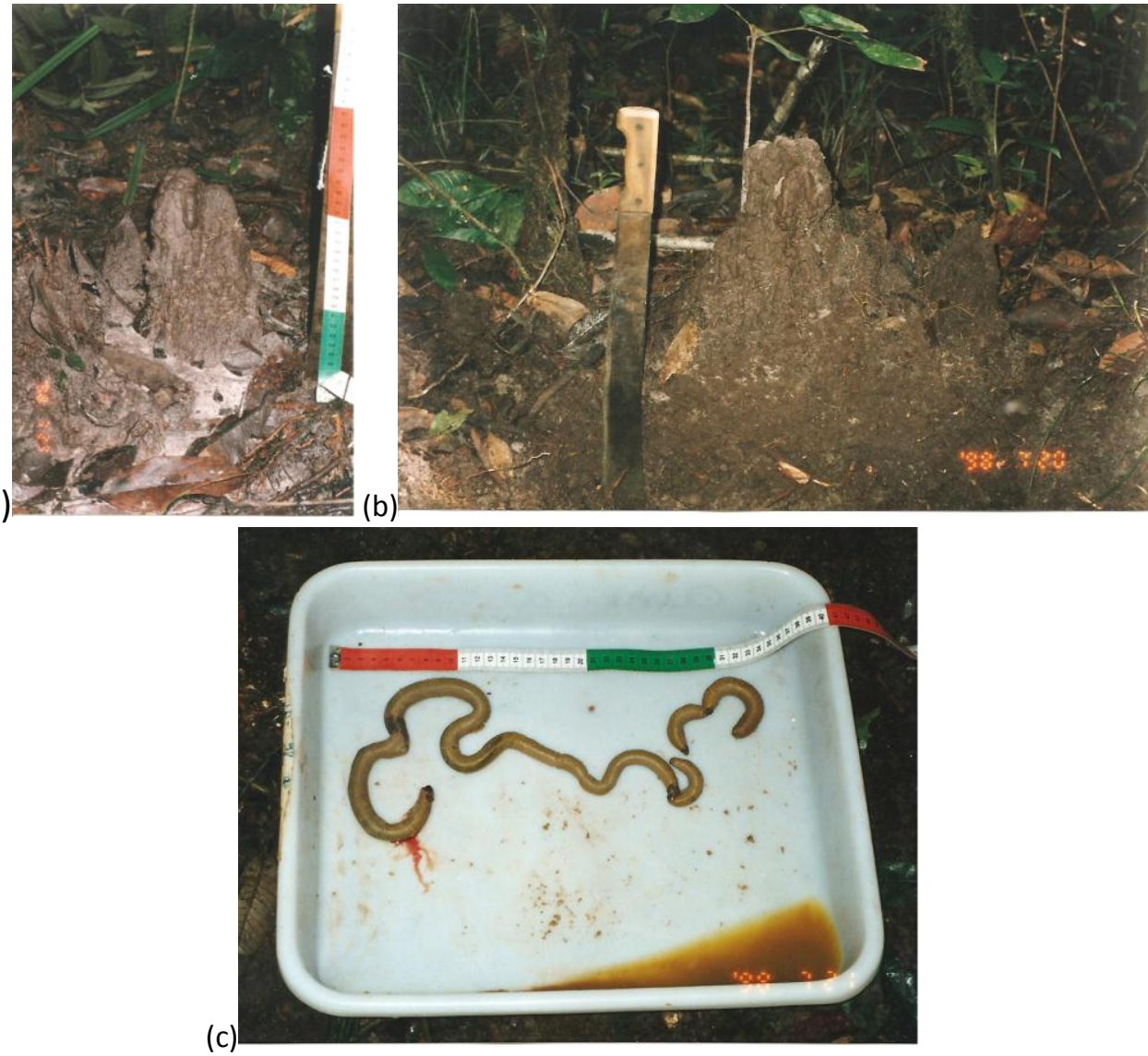

Foto 2. (a) e (b) Montículos de dejeções de minhocas sobre Podzóis hidromórficos de Cucuí, AM e (c) o espécime envolvido. [Fotos (a) e (c) A. L. Mafra, (b) A. A. W. Miklós].

$\checkmark \quad$ A floresta equatorial de Cucuí, sobre solos extremamente arenosos e permanentemente inundados, dependeria, em parte, da reciclagem de nutrientes - decomposição da serapilheira e formação do horizonte A - comandada pelas minhocas.

$\checkmark$ A incorporação pelas minhocas do aporte anual de biomassa da floresta equatorial (montículos e horizonte A) e a estocagem de carbono no horizonte Bh poderiam corresponder a um importante sistema de estocagem de carbono no solo. $\mathrm{O}$ desmatamento dessas áreas poderia, eventualmente, afetar o balanço global de carbono e o aquecimento global.

$\checkmark$ Após um desmate na planície inundada com solos arenosos, o reinício da vegetação também dependeria, em grande parte, destas minhocas. Na foto $3 b$ ilustra-se o reinício da vegetação após desmate. O horizonte A decapitado expõe o horizonte E álbico (areia branca). A recomposição vegetal dependeria de uma simbiose com as minhocas. Pois, as 
mudas das essências florestais se multiplicam e se desenvolvem em ilhas, exatamente lá onde se formam os montículos de excrementos das minhocas.

(a)
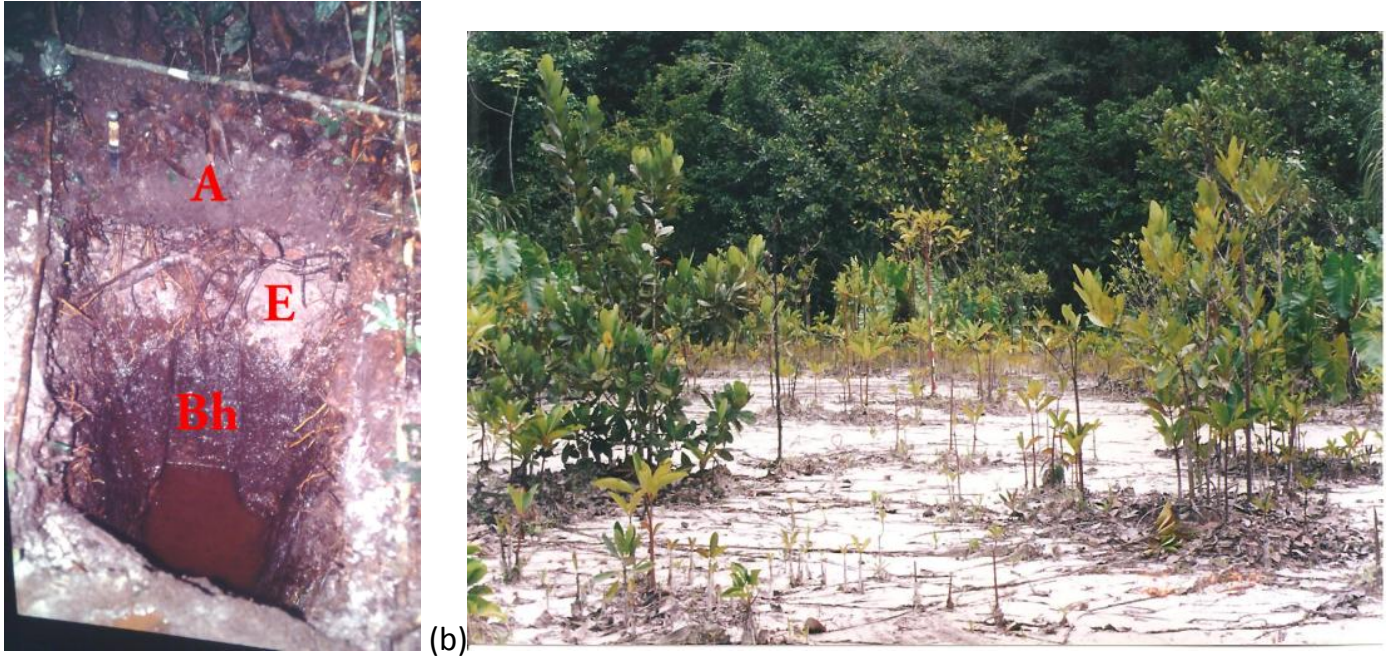

Foto 3. (a) Podzol hidromórfico; de cima para baixo: Horizonte superficial bruno escuro (Horizonte A),

Horizonte E álbico (areia branca) e Horizonte B húmico (Bh). No fundo da trincheira, o lençol freático, rebaixado artificialmente, de coloração marrom escura e (b) Área desmatada sobre solos arenosos inundados (areias quartzosas ${ }^{5}$ e podzóis hidromórficos), recolonização vegetal e animal. Os primeiros brotos vegetais se desenvolvem e formam as primeiras folhas. À medida que as folhas caem sobre o solo as minhocas as ingerem, decompõem e misturam com matéria mineral e formam as primeiras dejeções e montículos. Ilhas de espécies

arbóreas e arbustivas se desenvolvem sobre os montículos de excrementos de minhocas. É um caso de simbiose animal - vegetal. Trata-se do início do processo de regeneração da floresta equatorial. [Fotos (a), (b)

A. A. W. Miklós].

$\checkmark$ O sistema pedológico de transformação Latossolo Amarelo - Podzol hidromórfico (Mafra et al., 2002) que dá origem às planícies inundadas do alto Rio Negro poderia corresponder, também, a um importante sistema de estocagem de carbono no oceano. Primeiro, os Latossolos se transformam em Areias Quartzosas por processo de dissolução das argilas (acidólise em meio hidromórfico). Em meio arenoso e inundado sobrevêm as minhocas "gigantes" (foto 2 c) que passam a digerir a serapilheira da floresta equatorial e a formar os montículos com excrementos organominerais e o horizonte superficial (fotos $2 \mathrm{a}$ e b). Com a água da chuva, os montículos são desmantelados e lavados juntamente com o horizonte A. Essa "água de lavagem" marrom escura (foto 3 a) é rica em matéria orgânica, parte dissolvida, parte em suspensão. Ao percolar o perfil do solo arenoso, parte da matéria orgânica (fração mais grosseira) fica retida em uma determinada profundidade, lá onde ocorre uma redução da porosidade (formação do horizonte Bh). Outra parte, mais fina (hidrossolúvel e particular de baixo peso molecular, talvez, polímeros) tem fluxo livre e dá origem às

\footnotetext{
${ }^{5}$ Neossolos Quartzarênicos Psamíticos.
} 
nascentes de rios de coloração negra, ricos em matéria orgânica dissolvida. O Rio Negro

é um exemplo deste fenômeno. O carbono desse sistema vai parar nos oceanos.

A ação das minhocas sobre a formação e densidade de canais, sobre a física do solo (estabilidade estrutural, sínteses de muco bacteriano, gomas polissacarídicas e compostos pré-húmicos, secreções calcárias e floculação de compostos argilo-húmicos, porosidade, erosão, capacidade de retenção de água no solo e textura do solo) e sobre a química do solo (humificação, $\mathrm{pH}$, microflora, relação $\mathrm{C} / \mathrm{N}$, elementos trocáveis e totais, incorporação de nitrogênio e de calcário) não será abordada.

\section{Térmitas (cupins).}

A diversidade ecológica dos cupins resulta do seu comportamento ecológico (hábito alimentar e/ou construtor). Existem os consumidores de madeira, que têm protozoários intestinais para digestão da celulose, os arborícolas, os cultivadores de fungos, os herbívoros subterrâneos, os humívoros e os epígenos (fig. 2).

Caracterização da densidade populacional, biomassa, consumo alimentar e atividade metabólica de cupins e remonte vertical ou "turn-over" biológico (in Bachelier, 1978):

$\checkmark$ Maldague (1964), no Zaire, estudando uma população de 1.000 cupins $\mathrm{m}^{-2}$ e biomassa correspondente a $100 \mathrm{~kg} \mathrm{ha}^{-1}$ estimou, a partir da edificação de cupinzeiros epígenos, um remonte vertical de 22 ton de terra ha ${ }^{-1} \mathrm{ano}^{-1}$.

$\checkmark \quad$ Estudando a densidade populacional de cupins, Sands (1965) na Nigéria e Bodot (1967) na Costa do Marfim, deram conta de 1.000 a 10.000 cupins $\mathrm{m}^{-2}$.

$\checkmark \quad$ Lee e Wood (1971) levantaram variações de biomassa de cupins da ordem de 50 a 500 $\mathrm{kg} \mathrm{ha}^{-1}$.

$\checkmark$ Correlacionando densidade populacional de cupins e consumo alimentar, Josens (1974), num Cerrado da Costa do Marfim, relatou, em um ano:

○ 1.6 milhões de cupins forrageiros ha ${ }^{-1}$ consomem $40 \mathrm{~kg}$ matéria vegetal seca ha ${ }^{-1}$.

○ 4.5 milhões de cupins humívoros ha ${ }^{-1}$ consomem $30 \mathrm{~kg}$ de matéria vegetal seca ha ${ }^{-1}$.

○ 5 milhões de cupins fungívoros ha ${ }^{-1}$ consomem 1.300 a $1.600 \mathrm{~kg} \mathrm{ha}^{-1}$.

\footnotetext{
${ }^{6}$ Ao construir suas moradias, cupins e formigas transportam solo de baixo para cima, formando montículos de terra na superfície. Com as chuvas as estruturas biológicas abandonadas são desmanteladas e a terra é nivelada com a superfície topográfica; trata-se de um processo de inversão vertical de solo.
} 
- A biomassa total desses cupins era de $24 \mathrm{~kg} \mathrm{ha}^{-1}$.

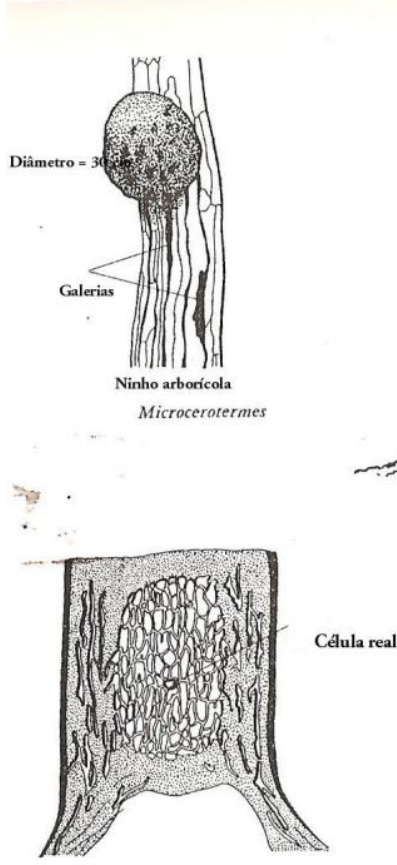

Esquema de um ninho de chedorhinotermes provisorius Grass construído em um velho tronco de árvore
(Guiné)

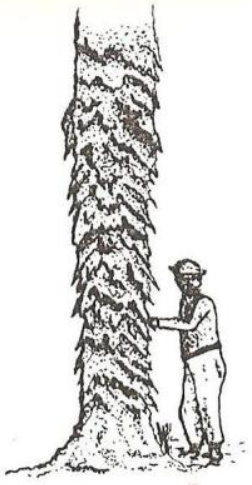

Amitermes excellens (Guiana)

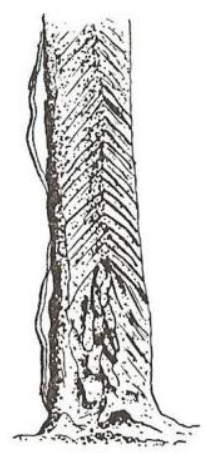

Procubitermes niapuensis ICongo)
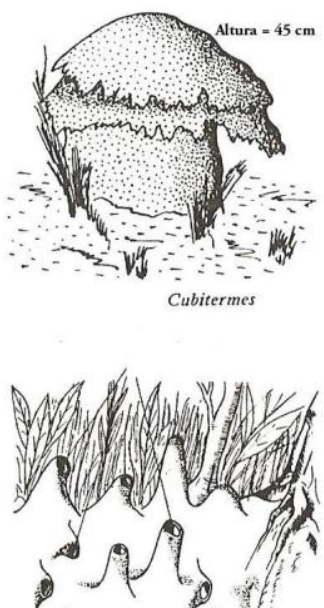

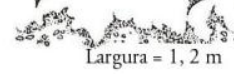
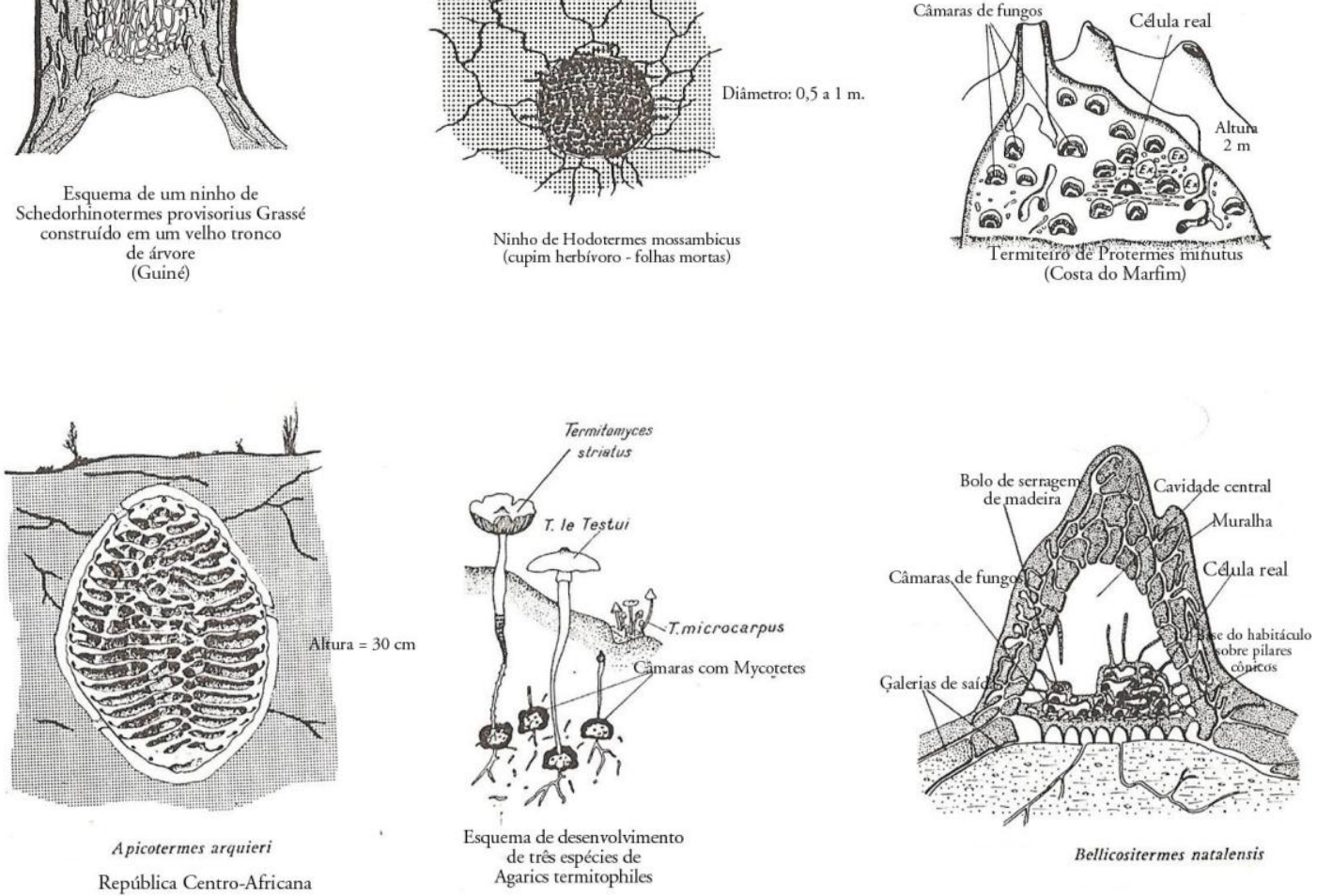

Bellicositermes natalensis

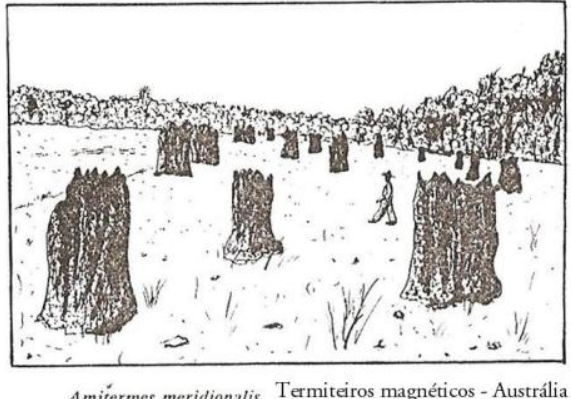

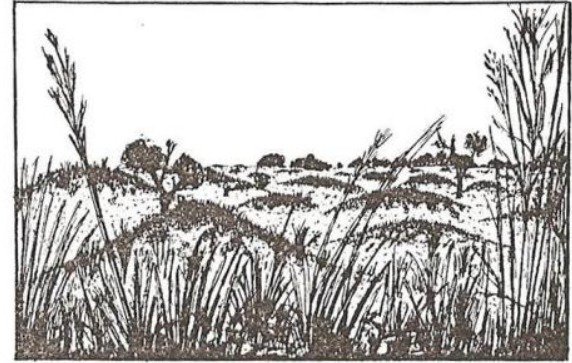

Bellicositermes rex Campo cerrado africano República Centro-African

Figura 2. Diversidade de termiteiros (in Bachelier, 1978). 
Com relação à destruição de fragmentos vegetais, Maldague (1964) verificou, numa floresta tropical do Zaire, um consumo de 6 a 7 ton matéria orgânica ha ${ }^{-1}$ ano $^{-1}$, o que corresponde a $50 \%$ da matéria vegetal caída no solo.

$\checkmark \quad$ Lee e Wood (1971) mostraram que o metabolismo dos térmitas, em região tropical com alta densidade populacional, girava em torno de $100 \mathrm{Kcal} \mathrm{m}^{-2} \mathrm{ano}^{-1}$. Em termos comparativos, o metabolismo dos grandes herbívoros - caprinos, ovinos, bovinos, equinos, girafídeos, elefantídeos - varia de 57 a $129 \mathrm{Kcal} \mathrm{m}^{-2}$ ano ${ }^{-1}$.

Dessa forma, poder-se-ia concluir, dentre muitas outras coisas, que o comportamento ecológico (alimentar e construtor) dos térmitas tem relevância no que concerne:

A formação de húmus e a incorporação de carbono no solo.

$\checkmark$ A ciclagem do carbono nas zonas intertropicais.

$\checkmark$ A dinâmica do $\mathrm{CO}_{2}$ e o aquecimento global (efeito estufa).

$\checkmark$ A morfologia do solo e a inversão de matéria mineral.

Ação dos cupins sobre a morfologia do solo: biogênese de latossolos e stone-lines e remonte vertical

Em outubro de 1992, defendi na Universidade de Paris VI, França, uma tese de doutorado sobre a biodinâmica de solos da região de Botucatu. Comprovou-se a biogênese dos latossolos e horizontes B latossólicos, de outras classes de solos, pela ação de cupins e formigas (Miklós, 1992). A estrutura granular muito pequena dos Latossolos, constituída por microagregados esféricos ou ovais (principalmente, $<300 \mu \mathrm{m}$, ) (foto 4a), resulta da ação desses animais, do seu comportamento ecológico. Ao construírem suas moradias no interior ou na superfície dos solos, cupins e formigas moldam com as suas mandíbulas microagregados esféricos ou ovais $(<0,3 \mathrm{~mm})$ e os utilizam como unidade elementar de construção.

A foto 5 apresenta, numa sequência de imagens, o surgimento dos primeiros "germes" da microestrutura latossólica ${ }^{7}$, na passagem da rocha alterada (isalterita) para o horizonte Bw (B latossólico). No horizonte C (transição rocha - Bw), rico em câmaras de cupins endógenos (foto 5a) e raízes, as plaquetas de isalterita de basalto se justapõem a domínios microagregados. Entre uma plaqueta e outra (separadas por diáclases) observam-se as

${ }^{7}$ Os primeiros microagregados. 
raízes, os cupins e os microagregados (foto $5 b$ e $5 c$ ). E na foto $5 d$, os cupins que fabricam os microagregados.
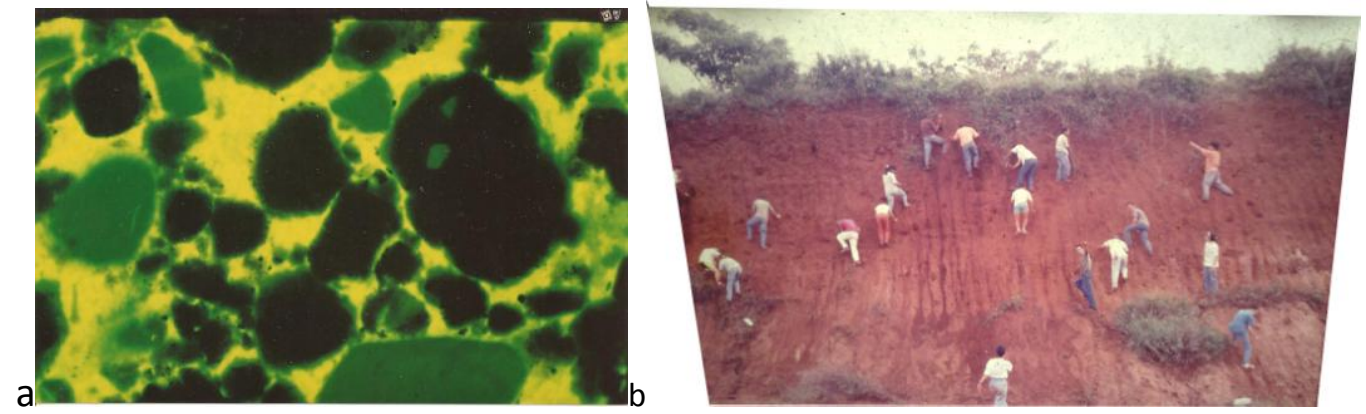

Foto 4. (a) Lâmina delgada impregnada com pigmento fluorescente sob luz ultravioleta em microscópio ótico. Micrografia da microestrutura do horizonte B latossólico da Vertente Lavapés, Botucatu, SP (Miklós, 1992). O maior microagregado oval à direita, em posição de $45^{\circ}$, tem $250 \mu \mathrm{m}$ em seu eixo maior e (b) Perfil de Latossolo

Vermelho (Latossolo Roxo) sobre diabásio, Piracicaba, SP; aula de campo com alunos da ESALQ / USP. A profundidade dos latossolos pode ultrapassar várias dezenas de metros. [Fotos (a), (b) A. A. W. Miklós].
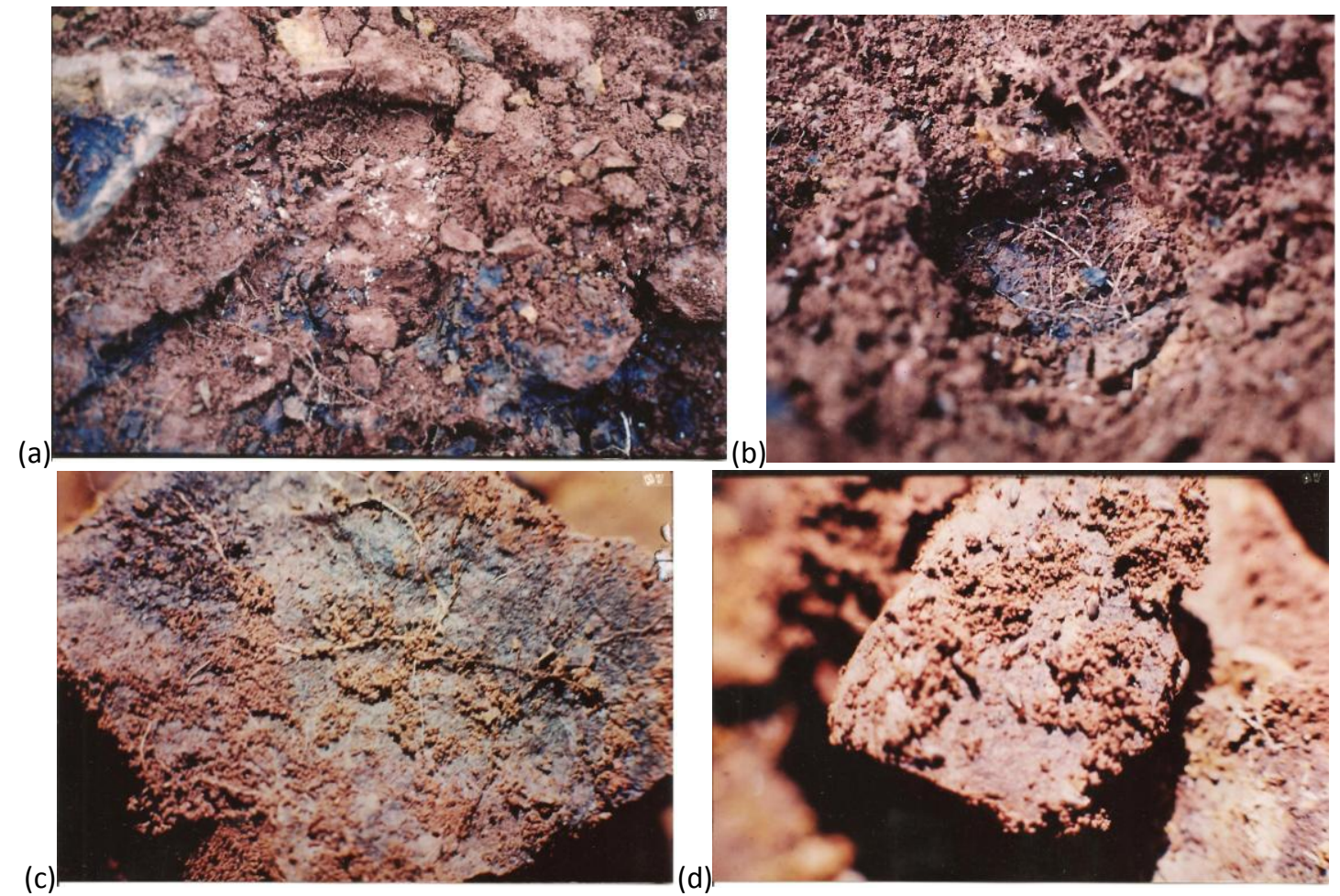

Foto 5. (a) Transição entre a rocha basáltica e o horizonte B latossólico; presença de câmaras de cupins, os cupins aparecem como "pontinhos" brancos, de plaquetas de isalterita de basalto, de domínios

microagregados entre as plaquetas e muitas raízes; (b) Na transição entre o horizonte C e a alterita, entre uma plaqueta de isalterita de basalto e outra, separadas por diáclase, observam-se: as raízes, os cupins ("pontinhos brancos") e os microagregados; (c) Detalhe da superfície de uma plaqueta de basalto que foi separada da outra: as raízes e, ao lado, os microagregados e (d) Cupins e os microagregados por eles fabricados. [Fotos 5 (a), (b), (c) e (d) A. A. W. Miklós].

O primeiro a propor a origem biológica dos latossolos em escala global foi Eschenbrenner (1986); mas, de modo indireto. Vincent Eschenbrenner montou um protocolo experimental com um termiteiro em laboratório e demonstrou a identidade entre os microagregados 
fabricados pelos cupins e os microagregados de latossolos. Mais recentemente, outros autores reconfirmaram a origem biológica da microestrutura dos latossolos pela ação de cupins (Schaefer, 1998; Graminha, 2001).

A figura 3 mostra a repartição geográfica dos latossolos no Brasil. Em outros termos, afirmaria que mostra, igualmente, a escala de atuação de cupins e formigas na biogênese latossólica e acrescentaria, ainda, que a figura não inclui os horizontes latossólicos de outras classes de solos (sobreposição Bt / Bw, por exemplo), tampouco, coberturas não latossólicas sobre stone-lines.

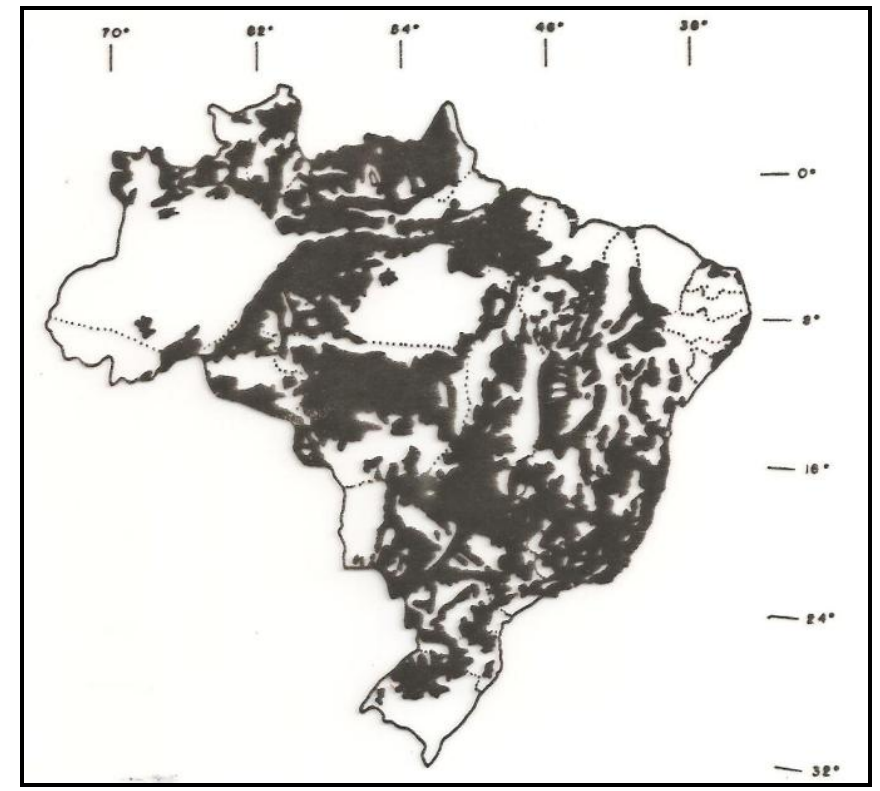

Figura 3. Distribuição dos Latossolos no Brasil (EMBRAPA, 1981).

Além da biogênese dos Latossolos, Miklós (1992) demonstrou a origem biológica (cupins e formigas, igualmente) da organização espacial de stone-lines (foto 6a). Devido ao seu hábito construtor (foto $6 \mathrm{~b}$ ) e alimentar, tais animais coletam terra em profundidade e as depositam em superfície. O limite de tamanho dos materiais que cupins ${ }^{8}$ conseguem transportar com suas mandíbulas é, aproximadamente, inferior a 0,5 $\mathrm{mm}$. Nessa dinâmica de transporte de material pedológico de baixo para cima ("turn-over" biológico), sobra o material mais grosseiro (seixos, nódulos ferruginosos, nódulos litoreliquiais, nódulos argilosos, etc.) ${ }^{9}$ que paulatinamente se alinha horizontalmente em determinadas profundidades e paralelamente à superfície topográfica, na medida da evolução do modelado. A origem dos seixos provém,

\footnotetext{
${ }^{8}$ E formigas.

${ }^{9}$ Composição das stone-lines, geralmente.
} 
sistematicamente, de níveis conglomeráticos de rochas sedimentares que são "apagados" (pedoplasmação) pelo intemperismo.

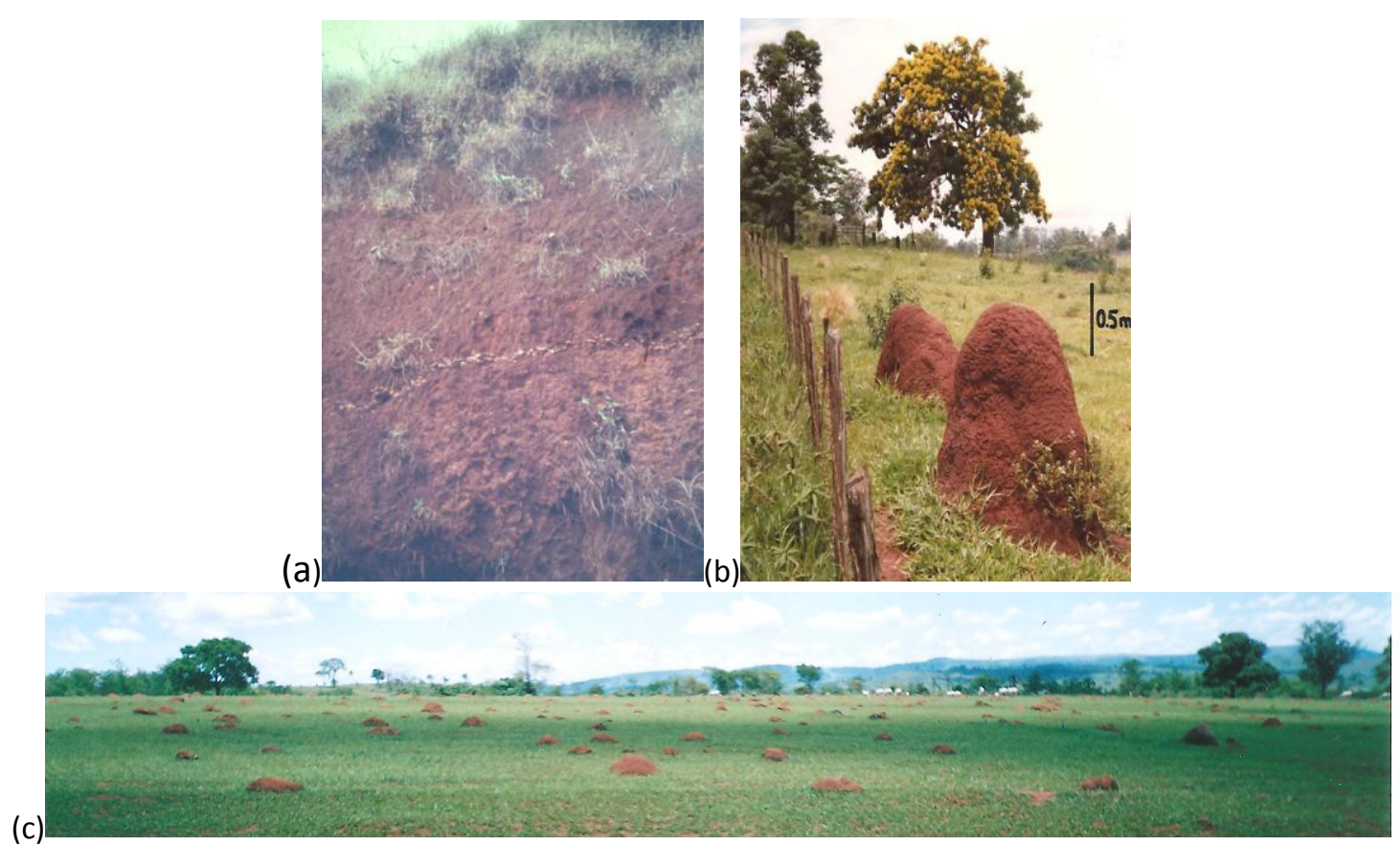

(c)

Foto 6. (a) Stone-line sobreposta por, aproximadamente, 10 metros de solo; (b) Edifícios de Cornitermes cumulans; o semiadulto, na frente da foto, pesa, aproximadamente, $1000 \mathrm{~kg}$ e o mais jovem, atrás, $500 \mathrm{~kg}$; (c) Pasto com cupinzeiros jovens de Cornitermes cumulans.

A título ilustrativo, para fabricar o perfil de solo (de $10 \mathrm{~m}$ ) acima da stone-line (foto 6a), em 1.000 anos, pela atividade dos Cornitermes ("turn over" biológico), seria necessária uma taxa de remonte de $1 \mathrm{~cm} \mathrm{ano}^{-1}$ (100 ton $\mathrm{ha}^{-1}$ ano $^{-1}$ ). Como estimativa grosseira, considerando a densidade aparente igual a 1 ton $\mathrm{m}^{-3}$ e um ciclo biológico de 10 anos para se atingir um termiteiro adulto, 1.000 anos se subdividiriam em 100 ciclos. Ou seja, precisaríamos de uma densidade populacional de Cornitermes cumulans adultos (1000 kg / edifício) de 100 cupinzeiros adultos $\mathrm{ha}^{-1}$ se renovando a cada 10 anos. A densidade de termiteiros na foto acima (foto 6c) é de, aproximadamente, 150 - 200 cupinzeiros / ha.

A análise estrutural da cobertura pedológica (Humbel, com. or., Bocquier, 1973; Boulet et al. 1982, Ruellan, 1985; Queiroz Neto et al., 1987; Miklós, 1992) foi definitiva para a demonstração científica da biogênese dos latossolos e da organização espacial de stone-lines e seu reconhecimento internacional. A tese foi revisada e referenciada pela União Internacional de Ciência do Solo (Miklós, 1992 in Bulletin of the International Union of Soil Science, 1993). 
Os aloctonistas, citando somente alguns autores brasileiros (Ab'Saber, 1969; Penteado, 1976; Mousinho; Bigarella, 1969), insistiram na teoria de que o material que se encontra acima da stone-line provém de fora (aloctonia), de sítios à montante onde o material foi erodido e, subsequentemente, transportado e sedimentado sobre paleopavimentos detríticos. A linha de pedras ou paleopavimentos detríticos teria sido originada em paleoclima árido ou semiárido (semelhantemente ao que existe hoje em regiões semiáridas e áridas) e teria sido soterrada por sedimentos após mudança climática. "Na retrospectiva crítica sobre a pedologia", Espindola (2008) discorre a fundo sobre as diferentes correntes de pensamento.

A comprovação da origem biológica das stone-lines e remonte vertical pela fauna do solo não é atual, ao contrário, é antiga e recorrente (In Miklós, 1992: Ruhe, 1956; Boyer, 1959; Grassé e Noirot, 1959; De Craene e Laruelle, 1965; Leveque, 1969, Fauck, 1971; Lee e Wood, 1971; Bachelier, 1978; Raunnet, 1979; Roose, 1980; Neel, 1983; Wielemaker, 1984).

Retomando uma citação do termitólogo francês Philippe Grassé (in Bachelier, 1978): “Em superfícies por diversas vezes maiores do que a da França, o solo da África foi remanejado, embebido em saliva e trabalhado pelos térmitas; as consequências pedológicas são extremamente importantes". Os cupins ocupam as paisagens intertropicais desde o mesozoico, há 110 Mi de anos (Fontes; Vulcano, in Fontes; Berti, 1998).

Miklós $(1992,1998)$ estimou, também, a taxa de remonte vertical de material pedológico trazido de baixo para cima pelos cupins e formigas graças à presença de fragmentos de carvão em determinadas profundidades (fig. 4a e b). Com apoio das datações com C-14 determinou-se taxas de turn-over biológico ou velocidade de formação do perfil de solo, de 0,21 a $0,35 \mathrm{~mm} \mathrm{ano}^{-1}$. Com essas taxas de remonte se constrói um perfil de 2 a 3,5 $\mathrm{m}$ de profundidade em 10.000 anos. O que é, evidentemente, subestimado, pois não se considerou as erosões mecânica e geoquímica. 


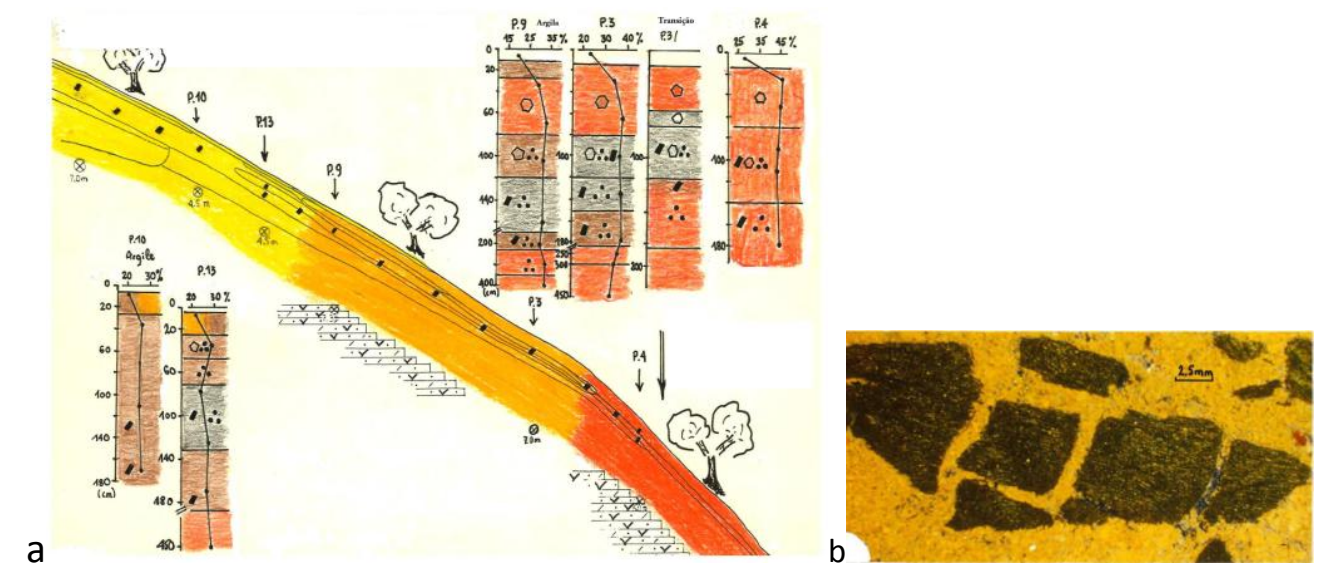

Figura 4. (a) Distribuição espacial dos carvões vegetais na Vertente Lavapés e (b) Bloco impregnado com resina sob lupa binocular e luz incidente. Detalhe de um fragmento de carvão. As idades dos carvões variam entre 4.400 a 6100 anos BP (Miklós, 1992).

Mais recentemente, alguns autores passaram a determinar a taxa de remonte vertical a partir de datações de carvão com C-14 e com isso estimar a velocidade de formação dos perfis de solos (Boulet et al., 1995; Pessenda et al., 1996).

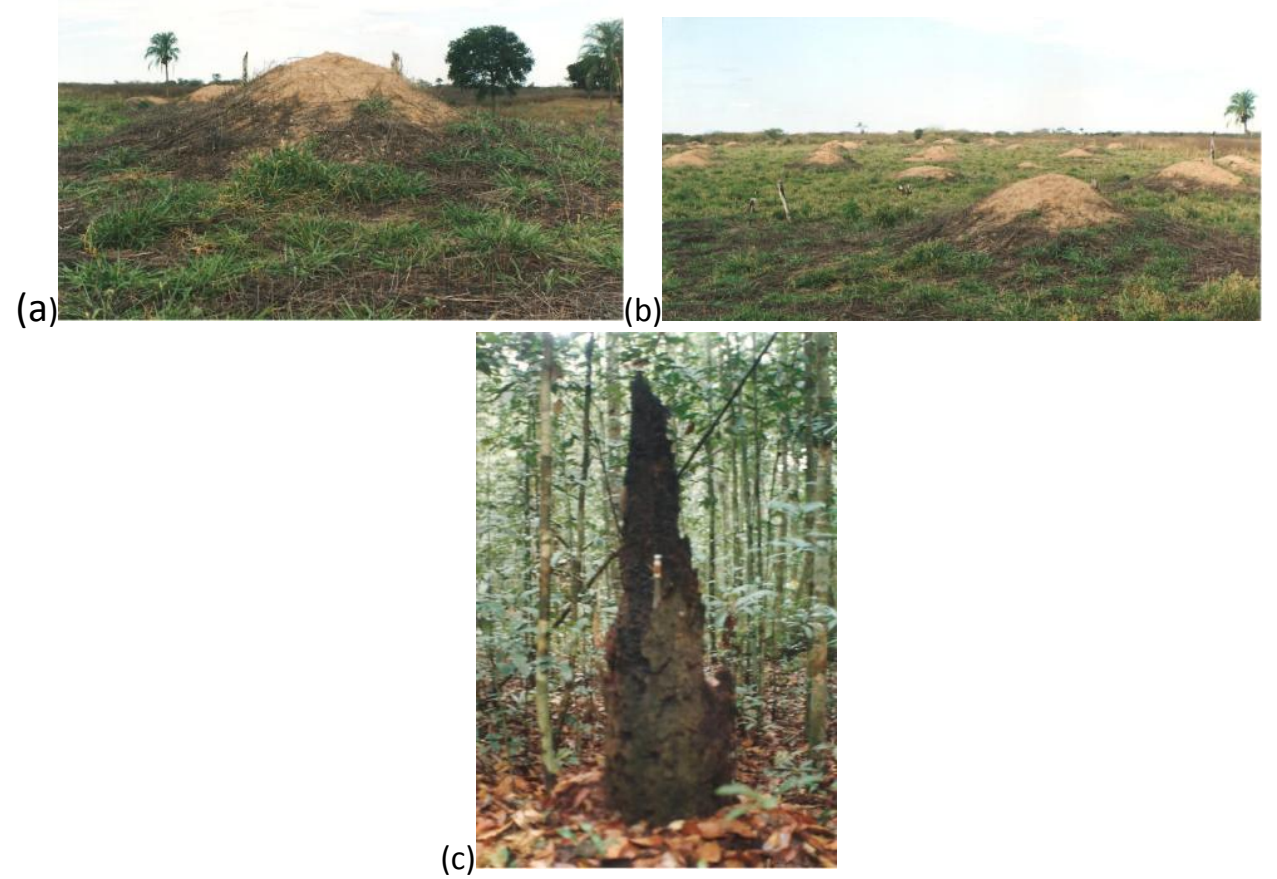

Foto 7. Termiteiros: (a, b) Estruturas fósseis, cupinzeiros inativos com 2 a $3 \mathrm{~m}$ de altura e 20 a $30 \mathrm{~m}$ de diâmetro; bacia do Rio São Francisco, Matias Cardoso, norte de Minas Gerais. e (c) Cupinzeiro de 3 m de altura sobre Latossolo Amarelo; margem direita do Rio Negro, São Gabriel da Cachoeira, AM.

Como para as stone-lines, a determinação das taxas de remonte vertical ou estimativa da velocidade de formação do solo pela fauna do solo (cupins e formigas) é matéria antiga e recorrente: 
$\checkmark$ O recorde no que diz respeito ao montante do "turn-over" biológico ficou, até o momento, com Philippe Boyer (1973) que estudou ${ }^{10}$ o Bellicositermes rex ("cupinzeiros gigantes") na República Centro-Africana (fig. 2) e determinou taxas de remonte de 1 a 4 $\mathrm{cm} \mathrm{ano}^{-1}$, ou seja, recobrimentos de 1.000 a $4.000 \mathrm{~m}^{3} \mathrm{ha}^{-1} \mathrm{em} 10$ anos (100 a 400 ton ha$\left.1 \mathrm{ano}^{-1}\right)$, considerando a erosão. Os termiteiros dessa espécie atingem as maiores dimensões já observadas até então; 30 m de diâmetro por 2 metros de altura.

$\checkmark \quad$ No Brasil, os maiores cupinzeiros por mim observados (foto 7) situam-se: (a) ao longo da bacia do Rio São Francisco, aparecendo em escala regional na densidade de edifícios observada (foto 7b) e (b) em São Gabriel da Cachoeira, AM, sob floresta equatorial (foto 7c). Os primeiros são muito semelhantes ao Bellicositermes rex da República CentroAfricana (fig. 2), mas não se encontram mais em atividade. Trata-se de estruturas fósseis em relação, provavelmente, com a evolução quaternária recente da bacia do Rio São Francisco.

$\checkmark \quad$ Lee et Wood (1971), negligenciando as erosões geoquímica e eólica, calcularam que na Austrália a erosão dos diferentes cupinzeiros poderiam permitir a formação de um horizonte superficial com $10 \mathrm{~cm}$ de espessura $\left(1.000 \mathrm{~m}^{3} \mathrm{ha}^{-1}\right)$ em 250 a 1250 anos, em função das regiões e populações dos térmitas.

A ação dos térmitas sobre a física do solo (porosidade, canais, textura do solo, etc.), bem como, sobre a química do solo (matéria orgânica, elementos totais e trocáveis, pH, transformações e sínteses mineralógicas, etc.) não será abordada neste artigo.

\section{Formigas}

A figura 5 mostra as partes componentes de um formigueiro de saúva (Atta $s p$ ) com base em escavações; a figura humana servindo de escala (Jonkman, 1980). Nas escavações de Jonkman observa-se um homem dentro de uma câmara de dejeção. De longe, as saúvas constituem o gênero de formiga que mais transporta solo de baixo para cima, inversão vertical de solo (fotos $8 \mathrm{a}, \mathrm{b}$ e c).

\footnotetext{
${ }^{10}$ Doutorado de Estado; 12 anos de trabalho de tese, no antigo sistema Francês.
} 
Em Botucatu (Miklós, 1992), os sauveiros são muito abundantes, atingem mais de $10 \mathrm{~m}$ de profundidade e formam montículos em superfície de até uma dezena e meia de metros de diâmetro e mais ou menos meio metro de altura (foto 8a).
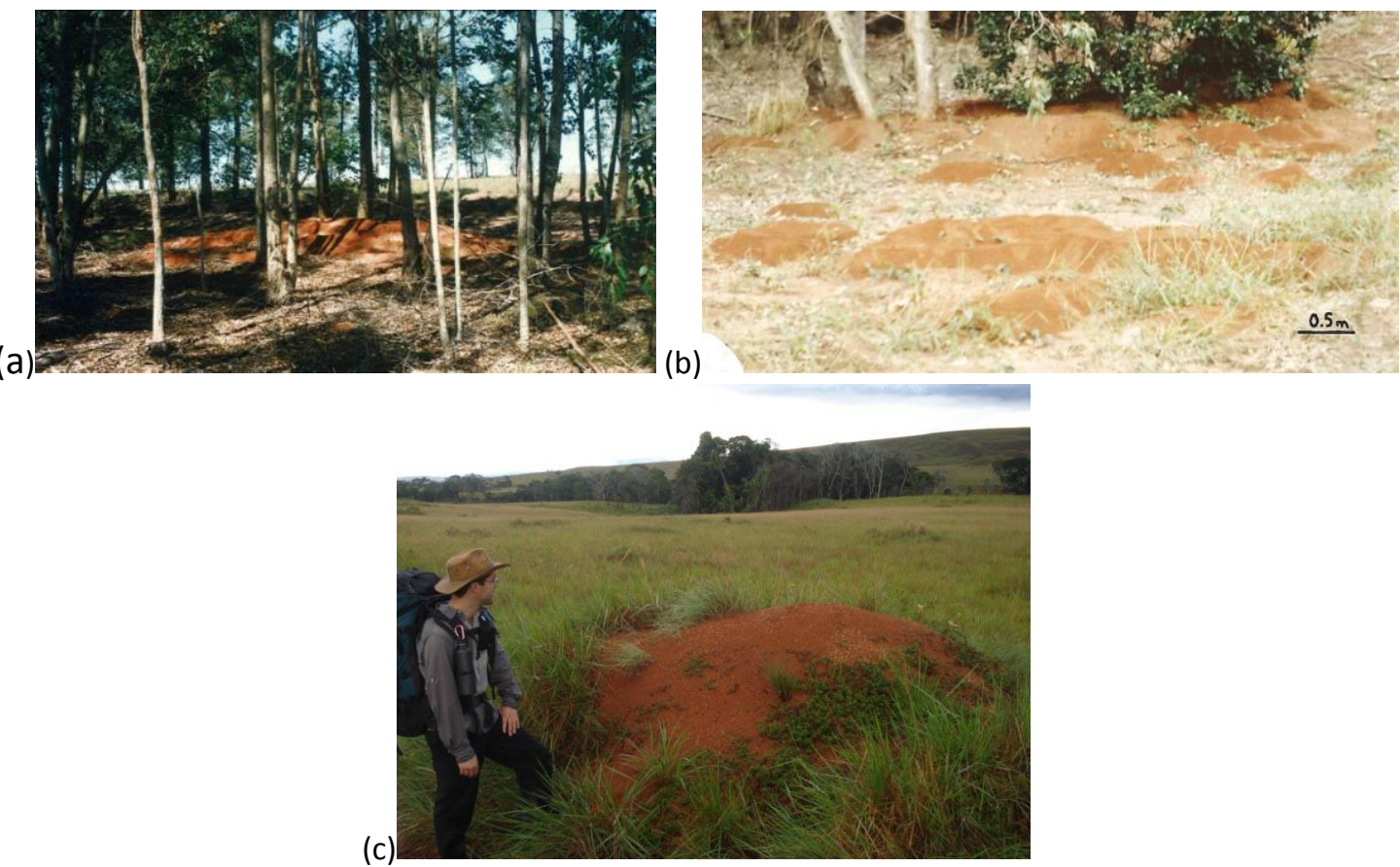

Foto 8. (a) e (b) Montículos de formigueiros de saúva constituídos de agregados granulares pequenos; o solo foi trazido de 10 metros de profundidade e (c) Montículo de formigueiro de Atta capiguara, no Parque Nacional do Monte Roraima, Venezuela. [Fotos (a), (b) e (c) A. A. W. Miklós].

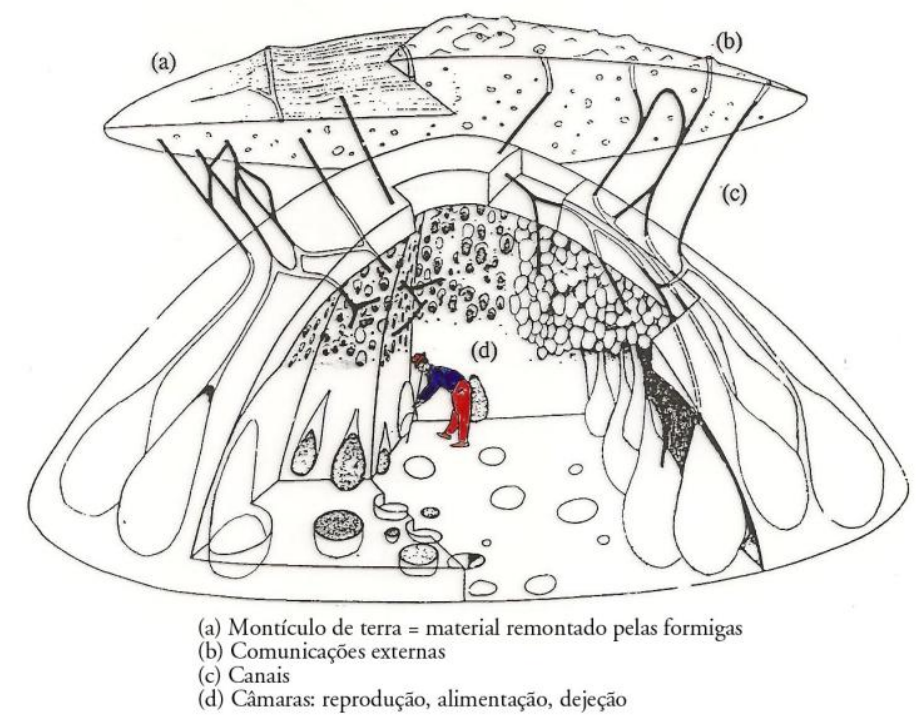

Figura 5. Partes componentes de um formigueiro de saúva (Atta sp). Visualização parcialmente fictícia de um formigueiro adulto, baseado em escavações; segundo Jonkman (1980).

E, em posição de topo e terço superior de encosta as saúvas foram responsáveis pela formação de horizontes de até $30 \mathrm{~cm}$ de espessura (fotos 9 e 10 e fig. 6) (Miklós, 1992). 
Após a morte do formigueiro, o solo dos montículos, se dispersa e se homogeiniza sobre a superfície topográfica (foto 9b). As folhas da cobertura vegetal caem e formam a serapilheira e novos vegetais e animais passam a colonizar o material superficial (foto 9c). Em 20 anos o material vermelho amarelo (5YR4/6) se transforma em bruno avermelhado escuro (5YR 3/3) e apaga a bioturbação das saúvas.

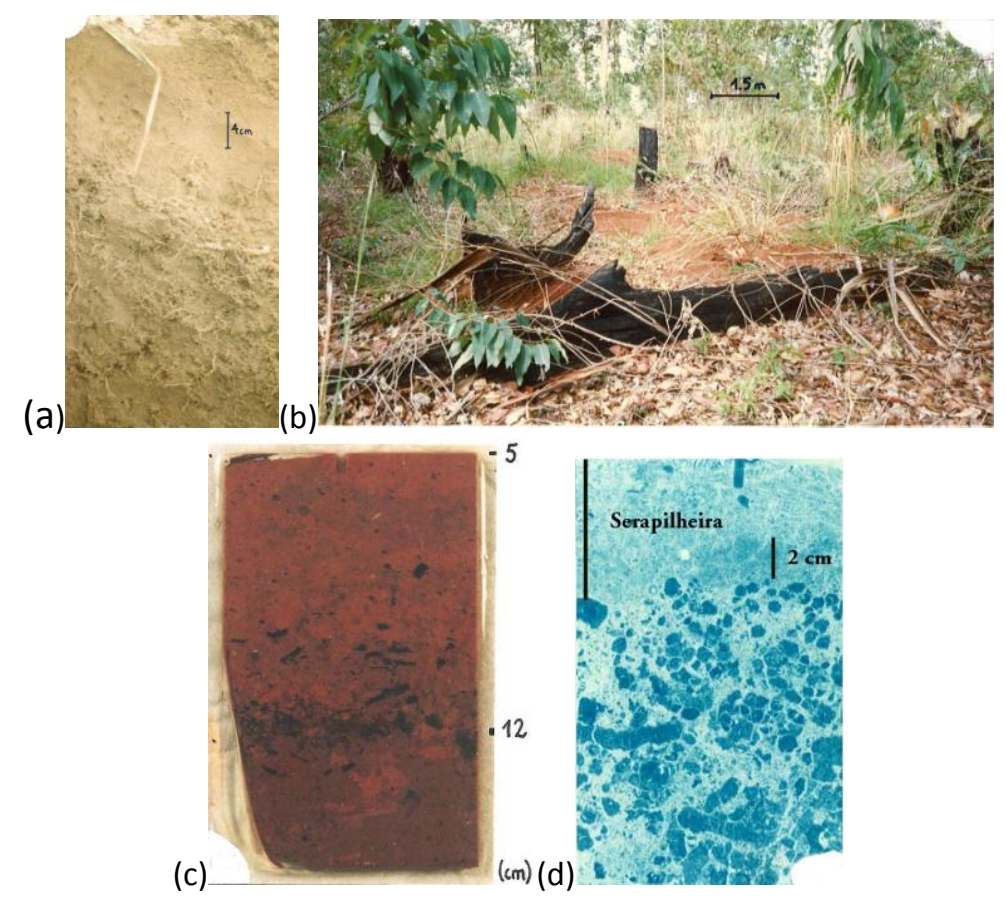

Foto 9. (a), (b) e (c) Solo vermelho amarelo trazido pelas formigas de $10 \mathrm{~m}$ de profundidade e depositado sobre o antigo horizonte superficial bruno escuro; (c) Bloco impregnado com resina sob luz incidente. Detalhe do horizonte bicolor 5YR4/6 e 3/3 $(5-12 \mathrm{~cm})$, formado pelas saúvas, recobrindo a antiga serapilheira $(12 \mathrm{~cm})$ e o antigo horizonte superficial bruno escuro $(>12 \mathrm{~cm})$. Rebioturbações sucessivas sobre o material vermelho amarelo dão origem ao horizonte bicolor (d) Bloco impregnado com resina e pigmento fluorescente sob luz ultravioleta. Detalhe da estrutura granular pequena e de alguns corpos cilíndricos de dejeções de minhocas do horizonte superficial sob a serapilheira de um Latossolo Vermelho Amarelo [Fotos (a), (b), (c) e (d) A. A. W. Miklós].

Cupins e formigas são os responsáveis, igualmente, pela origem da estrutura granular pequena $(\leq 0,6 \mathrm{~cm})$ de horizontes superficiais de solos arenosos, areno-argilosos e argiloarenosos (fotos 9d e 10).

Além dos agregados granulares, as saúvas, também, fabricam microagregados $(<300 \mu \mathrm{m})$ e horizontes B latossólicos. O horizonte B latossólico da parte montante da Vertente Lavapés Latossolo Vermelho Amarelo e antigo Latossolo Vermelho Escuro - é resultado, sobretudo da ação das saúvas. A diferença em relação aos cupins é que estes quando moldam o microagregado, adicionam saliva (substância rica em polissacarídeos), que aumenta a 
estabilidade estrutural. Os microagregados das saúvas não tem saliva e, portanto, se desfazem com maior facilidade, perdendo a forma original esférica, oval, rapidamente. Cupins têm maior necessidade de umidade, têm o corpo úmido e mole. As saúvas têm o corpo seco e coriáceo. Na toposequência estudada (Miklós, 1992) as saúvas se encontram nas partes mais altas, em latossolos areno-argilosos, sobre arenitos. Os cupins ocupam a meia-encosta e o terço inferior de vertente, onde os solos são mais úmidos e argilosos, sobre basaltos. A esfericidade dos microagregados moldados por cupins duram muito mais tempo, apresentam maior estabilidade estrutural.
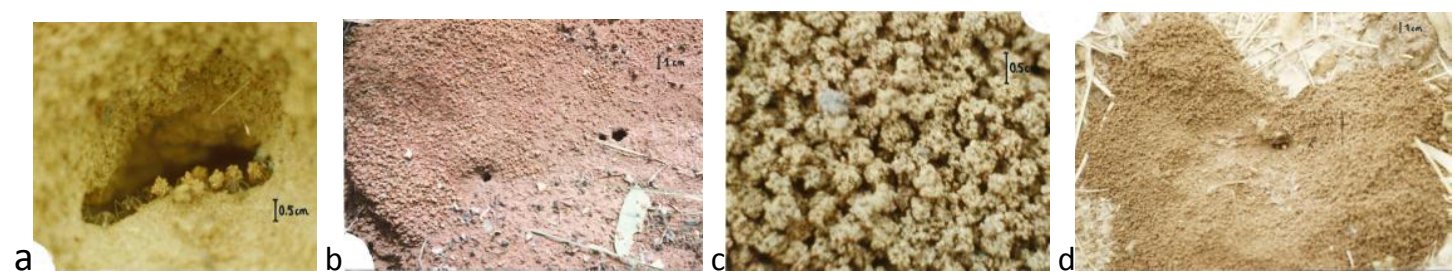

Foto 10. (a) Formigas transportando agregados granulares pequenos $(\leq 0,6 \mathrm{~cm})$, (b) Os agregados granulares são depositados ao lado das saídas dos formigueiros ("olheiros"); (c) Detalhe da subestrutura microagregada

dos agregados granulares. O microagregado moldado pelas mandíbulas desses animais correspondem a unidades elementares de construção e (d) Montículo de solo de térmita endógeno - Synthermes $s p$ - também, formado por agregados granulares $(\leq 0,8 \mathrm{~cm})$ com subestrutura microagregada. [Fotos (a), (b), (c) e (d) A. A. W. Miklós]

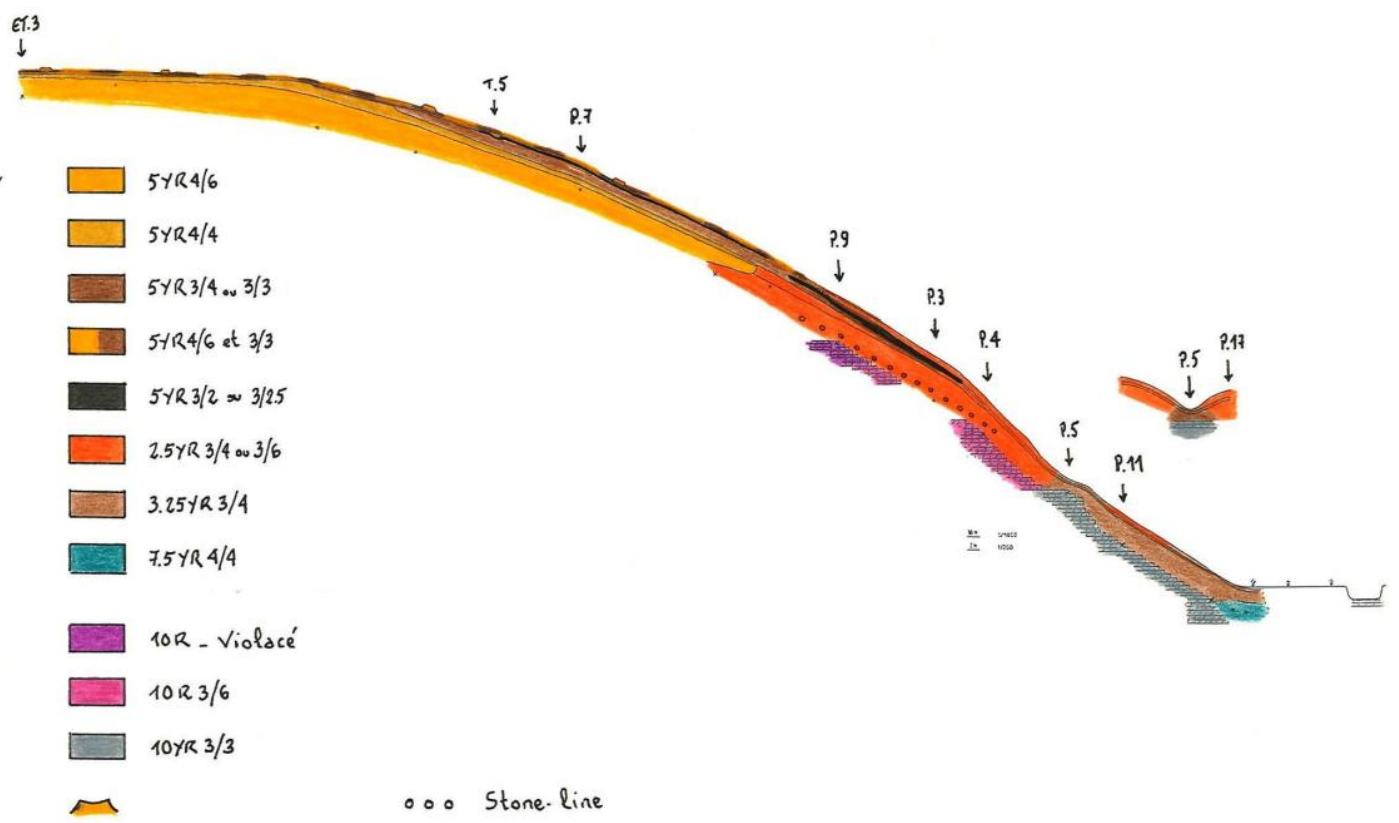

Figura 6. Diferenciação em cor da Vertente Lavapés (Miklós, 1992). Detalhe da extensão do horizonte bicolor $5 Y R 4 / 6$ e $3 / 3$ formado pelo remonte vertical das saúvas.

Jonkman (1978) estudou o papel das saúvas na evolução e diferenciação da vegetação (foto 11a e b). Observou fotos aéreas ao longo do tempo, 1944, 1965 e 1973. Nesse período o autor constatou uma transformação da vegetação, inicialmente, campo cerrado e depois 
cerrado. O mais importante assinalado por Jonkman foi que a diferenciação da vegetação se deu através da coalescência de ilhas de espécies arbóreas e que essas ilhas de espécies arbóreas ocorriam em cima dos montículos de formigueiros de saúva. Ao me deparar com tal artigo, revi minha área de pesquisa e notei o mesmo fenômeno (foto 11c); ilhas de espécies arbóreas e arbustivas de cerrado sobre os montículos de formigueiros abandonados. Observei o mesmo fenômeno no norte de Minas Gerais (foto 11d) e quando me dirigi ao Monte Roraima (foto 11e), só que desta vez, ilhas de espécies arbóreas e arbustivas de cerrado sobre cupinzeiros, em campo cerrado. Poder-se-ia traduzir o fenômeno da seguinte forma: "uma sucessão vegetativa sob a influência do comportamento ecológico de cupins e saúvas".

(a)
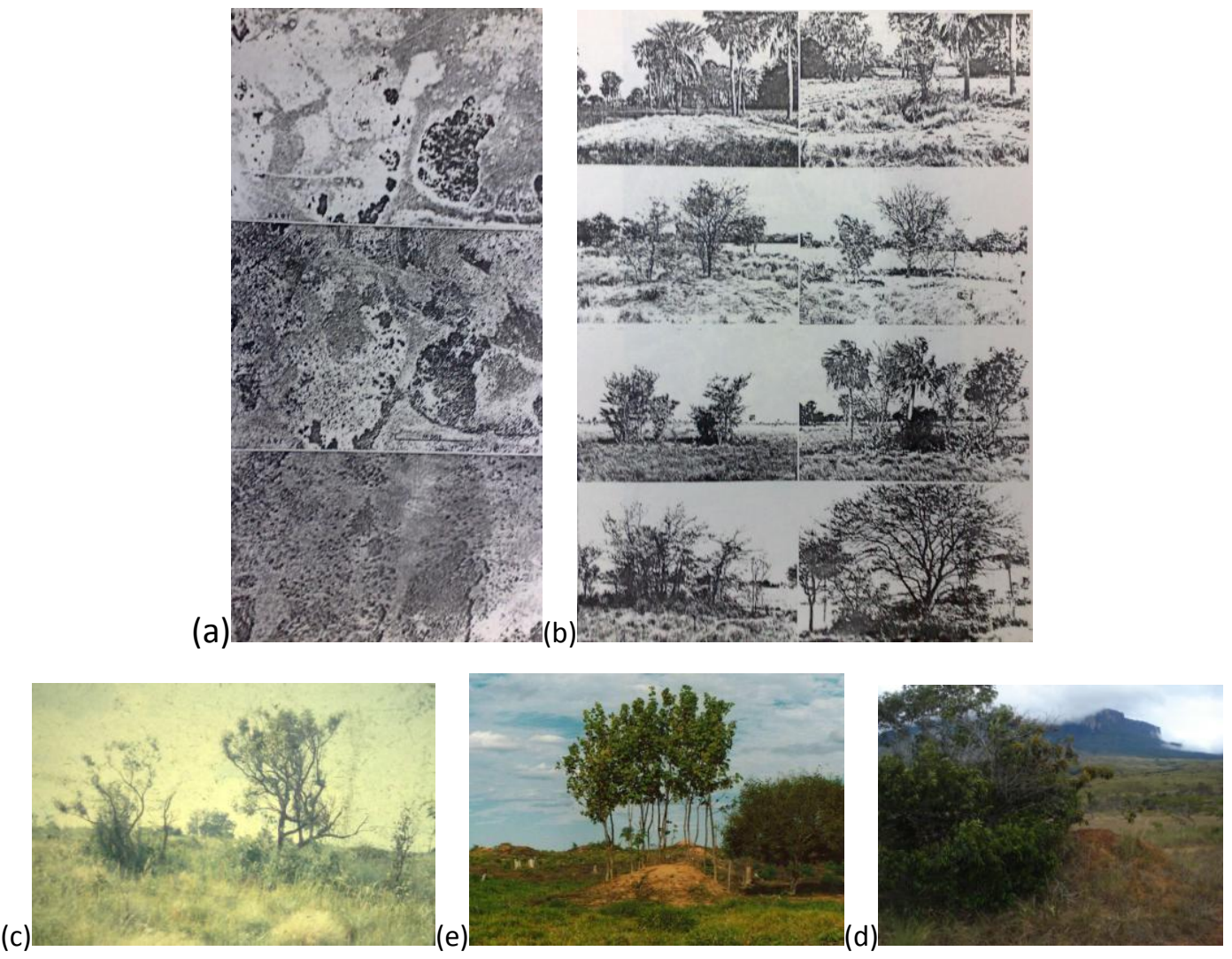

Foto 11. (a) Comparação de fotos aéreas da mesma área. De cima para baixo, 1944, 1965 e 1973 . No decorrer do tempo, ocorreu uma invasão relativamente rápida e densa de vegetação arbórea, quase que exclusivamente sobre os montículos de saúva. (b) Exemplos de ilhas de espécies arbóreas e arbustivas sobre os montículos dos formigueiros; (c) Ilha de espécies arbóreas e arbustivas sobre montículo de sauveiro abandonado em campo cerrado em Botucatu, SP; (d) Ilha de espécies arbóreas sobre cupinzeiro do norte de Minas Gerais e (e) Ilha de espécies arbóreas e arbustivas sobre um cupinzeiro ao lado do Monte Roraima.

$$
\text { [Fotos (a) e (b) J. C. Jonkman; Fotos (c), (d) e (e) A. A. W. Miklós] }
$$




\section{Os vegetais e suas raízes.}

Enquanto o principal polímero da crosta terrestre é o silício, o carbono o é da biosfera. A principal reação química no globo terrestre a envolver o elemento vivo (polimerização do carbono) é a fotossíntese:

$\checkmark \quad \mathrm{N}, \mathrm{P}, \mathrm{K}^{11}+\mathrm{nH}_{2} \mathrm{O}+\mathrm{nCO}_{2}+\mathrm{Luz} /$ Calor $\rightarrow \mathrm{C}_{6} \mathrm{H}_{12} \mathrm{O}_{6}$ (Biomassa viva) $^{12}$

Podemos traduzir essa reação de outra maneira ${ }^{13}$ :

$\checkmark$ Terra + Água + Ar + Luz $/$ Calor $=$ Vida $^{14}$.

No mundo mineral, na passagem da rocha para o solo, a principal reação química envolve a polimerização da sílica e tem como resultado a síntese (neoformação) de argila. O mineral primário anidro (componente da rocha) sob ação da água se dissolve (os elementos se separam), ocorrem perdas mais ou menos acentuadas ${ }^{15}$ em função do grau de solubilidade e das condições do meio, e os elementos restantes (elementos alcalinos, alcalinos terrosos, silício, alumínio e ferro) se recombinam com adição de água (foto 12) (Miklós, 1986).

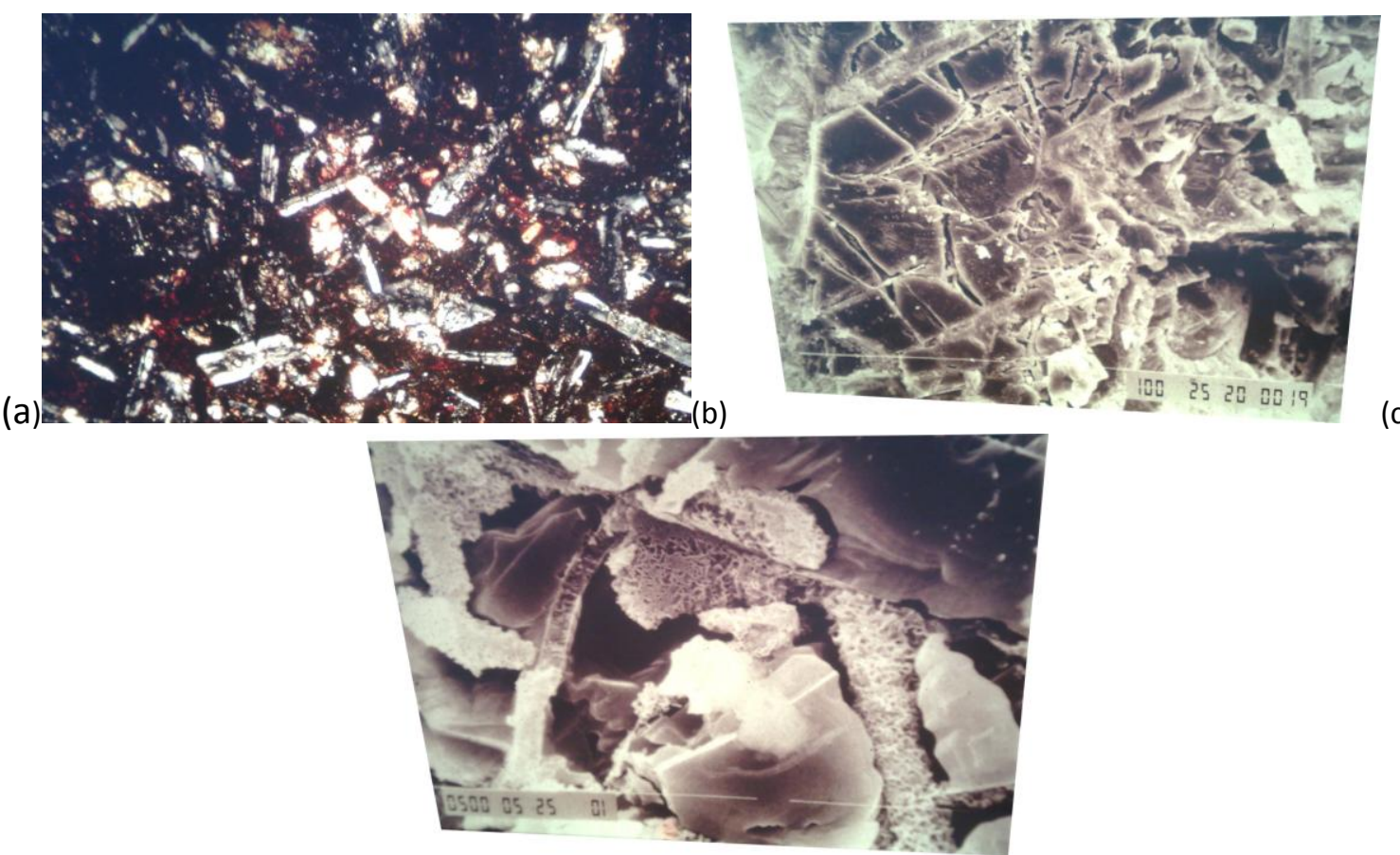

Foto 12. (a) Foto sob microscópio ótico e luz transmitida, polarização cruzada. Micrografia de basalto em início de alteração composto por: plagioclásios $(\leq 0,1 \mathrm{~mm})$, piroxênios, olivinas, ilmenita, magnetita e material amorfo; (b) Foto sob microscopia eletrônica de varredura (MEV). Detalhe de um piroxênio semialterado a partir dos eixos de clivagem do mineral (c) MEV - Detalhe da neoformação de nontronita (argilo-mineral do grupo da

\footnotetext{
${ }^{11}$ Nitrogênio, fósforo e potássio.

${ }^{12}$ Reação elaborada sem preocupação estequiométrica.

${ }^{13}$ Elementos etéreos.

${ }^{14}$ A somatória dos quatro elementos etéreos tem como efeito a vida. Vida manifesta na matéria (biomassa).

${ }^{15}$ Que se acumulam, no final das contas, no oceano: $\mathrm{Cl}, \mathrm{Na}, \mathrm{Ca}, \mathrm{Mg}$, $\mathrm{K}$, etc.
} 
esmectita), em estrutura alveolar ou em "ninho de abelha", em um veio de clivagem do piroxênio ${ }^{16}$. [Fotos (a), (b) e (c) A.A. W. Miklós]

A reação da alteração do piroxênio e neoformação de nontronita encontra-se representada abaixo $^{1718}$ :

$$
-(\mathrm{Ca}, \mathrm{Na})\left(\mathrm{Mg}, \mathrm{Fe}^{+2}, \mathrm{Fe}^{+3}, \mathrm{Al}\right)(\mathrm{Si}, \mathrm{Al})_{2} \mathrm{O}_{6}+\mathrm{H}_{2} \mathrm{O} \rightarrow\left(\mathrm{Si}_{(4-\mathrm{x})} \mathrm{Fe}_{\mathrm{x}}^{+3}\right) \mathrm{O}_{10}\left(\mathrm{Al}_{2}\right)(\mathrm{OH})_{2} \mathrm{M}^{+}
$$

Ou, simplificando:

- mineral primário anidro + água $\rightarrow$ argila.

Outro exemplo muito comum de neoformação de argila a partir da alteração de um mineral primário em clima tropical tem como reação ${ }^{19}$ :

$\checkmark$ Plagioclásio + Água $\rightarrow$ Caulinita

$\checkmark \mathrm{CaAl}_{2} \mathrm{Si}_{2} \mathrm{O}_{8}+\mathrm{H}_{2} \mathrm{O} \rightarrow \mathrm{Si}_{2} \mathrm{O}_{5} \mathrm{Al}_{2}(\mathrm{OH})_{4}$

Da mesma maneira que para o mundo vegetal, poder-se-ia traduzir essa reação da seguinte forma:

$\checkmark$ Terra + Água $=1 / 2$ Vida

Se no mundo vegetal, da associação dos quatro elementos - Terra + Água + Ar + Luz / Calor, o efeito é Vida "inteira" (1/1); no mundo mineral, na interface com o mundo do vivo (biosfera), da associação de apenas dois dos elementos, Terra + Água, o efeito seria, apenas, $1 / 2$ vida.

Assim, em relação ao processo do vivo, poder-se-ia dizer que temos uma sequência progressiva de diferenciação de baixo para cima:

$\checkmark$ Mundo mineral cristalino inanimado (zero vida) $\rightarrow$ Interface com a biosfera $\rightarrow$ Argila (1/2 vida) $\rightarrow$ Mundo vegetal (vida inteira).

É evidente que a consecução ideativa precedente não é de natureza intelectiva, mas sim imagética ${ }^{20}$ (Serres, 1999; Steiner, 1985). Destarte, os quatro elementos essenciais à vida "Terra, Água, Ar, Luz e Calor" que têm correspondência com os quatro estados da matéria "Sólido, Líquido, Gasoso, Calor"21" são elementos de natureza suprassensível, os mesmos referidos na Grécia Antiga (foto 13).

\footnotetext{
${ }^{16}$ Fotos 12 (b) e (c) MEV: o traço branco na parte inferior da foto corresponde a escala, respectivamente, 100 e $10 \mu \mathrm{m}$.

${ }^{17}$ Reação simplificada, sem preocupação estequiométrica ou de inserção dos componentes solúveis.

${ }^{18} \mathrm{M}^{+}=$metais alcalinos e alcalino-terrosos.

${ }^{19}$ Reação simplificada, sem preocupação estequiométrica ou de inserção dos componentes solúveis.

${ }^{20} \mathrm{Na}$ consciência imaginativa, matéria, forma e essência jamais se dissociam. O fio condutor deste caminho gnosiológico foi traçado por Aristóteles, Tomás de Aquino, Goethe e Steiner.

${ }^{21} \mathrm{O}$ calor deixou de ser considerado um estado da matéria a partir de Francis Bacon (1561 - 1626).
} 


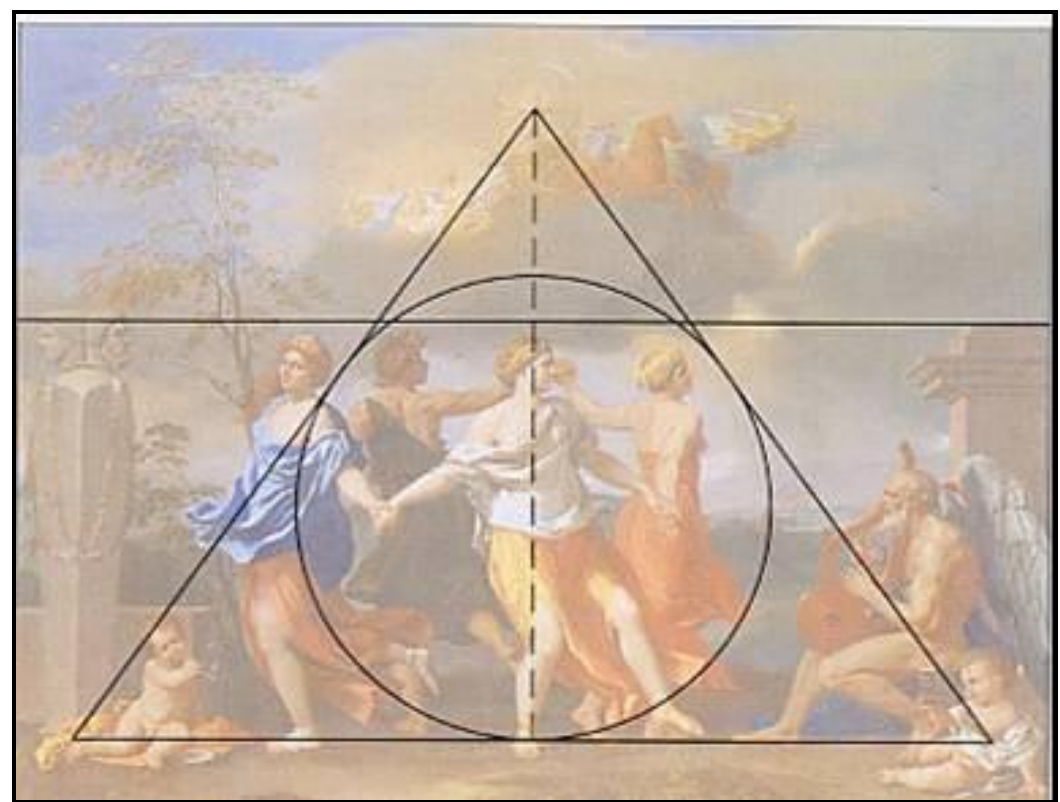

Foto 13. Pintura de Nicolas Poussain de 1638, com os quatro elementos - Terra, Água, Ar e Fogo - ligados ao sol (ápice do triângulo), representado por Apolo - Deus Solar.

Nessa pintura de Nicolas Poussain (1594 - 1665), as quatro mulheres representam a vida arquetipicamente organizada numa tetramembração (Azul - Elemento Terra; Verde Elemento Água; Vermelho - Elemento Ar; Branco - Elemento Luz / Calor) e tem sua origem no sol (ápice do triângulo), de onde provém a vida (como na fotossíntese). A luz do sol quando incide sobre um mineral tem como efeito, cor. E quando incide sobre o mundo vegetal, "como que desaparecendo no mundo vegetal" o efeito é vida. Vida que pode ser definida como sendo algo de natureza suprassensível; pois, não tem cor, cheiro, etc., é inatingível por órgãos sensoriais. Pode-se percebê-la somente a partir da sua manifestação na matéria (matéria $x$ essência).

Quando as folhas caem no solo e sofrem decomposição ocorre uma reação, inversa à da fotossíntese. Esquematicamente, a reação é a seguinte ${ }^{22}$ :

$\checkmark \quad \mathrm{C}_{6} \mathrm{H}_{12} \mathrm{O}_{6}+\mathrm{O}_{2} \rightarrow \mathrm{nCO} 2+\mathrm{nH} 2 \mathrm{O}+\mathrm{N}, \mathrm{P}, \mathrm{K}+$ liberação de energia (vida)

Entretanto a decomposição oxidativa e microbiana nunca é total, sempre uma parte dos compostos orgânicos em decomposição se repolimerizam produzindo compostos húmicos, que vão tomar parte na constituição da matéria orgânica do solo.

$\checkmark \quad \mathrm{C}_{6} \mathrm{H}_{12} \mathrm{O}_{6}+\mathrm{O}_{2} \rightarrow$ Húmus $+\mathrm{nCO} 2+\mathrm{nH} 2 \mathrm{O}+\mathrm{N}, \mathrm{P}, \mathrm{K}+$ energia (vida)

Vida reproduz vida. A liberação de energia (vida) a partir da decomposição da biomassa serve de alimento para todos os demais ciclos de vida da natureza.

\footnotetext{
${ }^{22}$ Quando a oxidação da matéria orgânica é total.
} 
Boissezon et al. (1973) apresentou a biomassa dos principais tipos de vegetação e o aporte anual de matéria vegetal em solos intertropicais:

$\checkmark$ Com relação à biomassa de uma floresta densa úmida sempervirente (floresta equatorial) tem-se, em peso seco os seguintes valores médios:

$\checkmark 40$ ton ha-1 de matéria verde e 90 de ton ha ${ }^{-1}$ raízes $^{23}$.

$\checkmark$ Num cerrado arbóreo, no Ghana, as proporções entre matéria verde e raízes são opostas:

$\checkmark$ 8,3 ton ha ${ }^{-1}$ de matéria verde para 3,9 ton ha-1 raízes.

$\checkmark$ Em floresta equatorial (valores médios) o aporte anual é de 16 ton ha- ${ }^{-1}$ ano $^{-1}$ de folhas verdes e 25 ton ha ${ }^{-1}$ ano $^{-1}$ no total.

$\checkmark$ E em cerrado arbustivo (valores médios) o aporte anual é de 8,3 ton ha ${ }^{-1}$ ano $^{-1}$ de folhas verdes e 11,5 ton ha $^{-1}$ ano $^{-1}$ no total.

O capital mineral encontra-se imobilizado na vegetação tropical. Em $\mathrm{kg} \mathrm{ha}^{-1}$, sem computar as raízes (Boissezon et al., 1973):

$\checkmark$ Em floresta equatorial antiga, na Costa do Marfim: 2200 N, 90 P, 255 K 445 Ca e 198 Mg.

$\checkmark$ Floresta equatorial mais nova, no Ghana: 570 N, 39P, 409 K, 523 Ca e 213 Mg.

$\checkmark$ Floresta densa úmida semidecídua, no Ghana: 450 N, 30 P, 276 K, 444 Ca, 189 Mg.

Muitos desses valores ultrapassam os teores de nutrientes contidos nos horizontes superficiais dos solos em questão.

A figura 7a apresenta a extensão das principais coberturas de alteração no Brasil (Melfi; Pedro, 1977). Percebe-se que ocorre uma incoerência termodinâmica na repartição dessas coberturas, qual seja, o domínio da alteração ferralítica sem gibbsita (Ki $\leq 2$ ) lá onde as precipitações e as temperatura são mais elevadas. Na figura $7 b$, onde se apresenta a composição mineralógica de latossolos amarelos da Amazônia (Lucas et al., 1993), também, ocorre uma contradição termodinâmica; o predomínio de caulinita em superfície e o aumento de gibbsita em profundidade. Em ambos os casos, termodinamicamente, deveria ser o contrário, ou seja, alteração ferralítica com gibbsita na Amazônia e maior quantidade de gibbsita na parte superior dos perfis. Pois, de um lado, na Amazônia encontram-se as maiores precipitações e temperaturas, ou seja, as melhores condições de alteração dos

\footnotetext{
${ }^{23}$ Convidamos o leitor a transpor, em imagem, a parte aérea da biomassa verde de uma floresta equatorial para o interior do solo, duplicando-a; daí vislumbrar a magnitude da ocupação do solo pelas raízes, no bioma em questão.
} 
minerais para neoformação de gibbsita (alitização ${ }^{24}$ ) e, de outro lado, nas partes superiores dos perfis, os processos de dissolução e lixiviação são mais intensos.
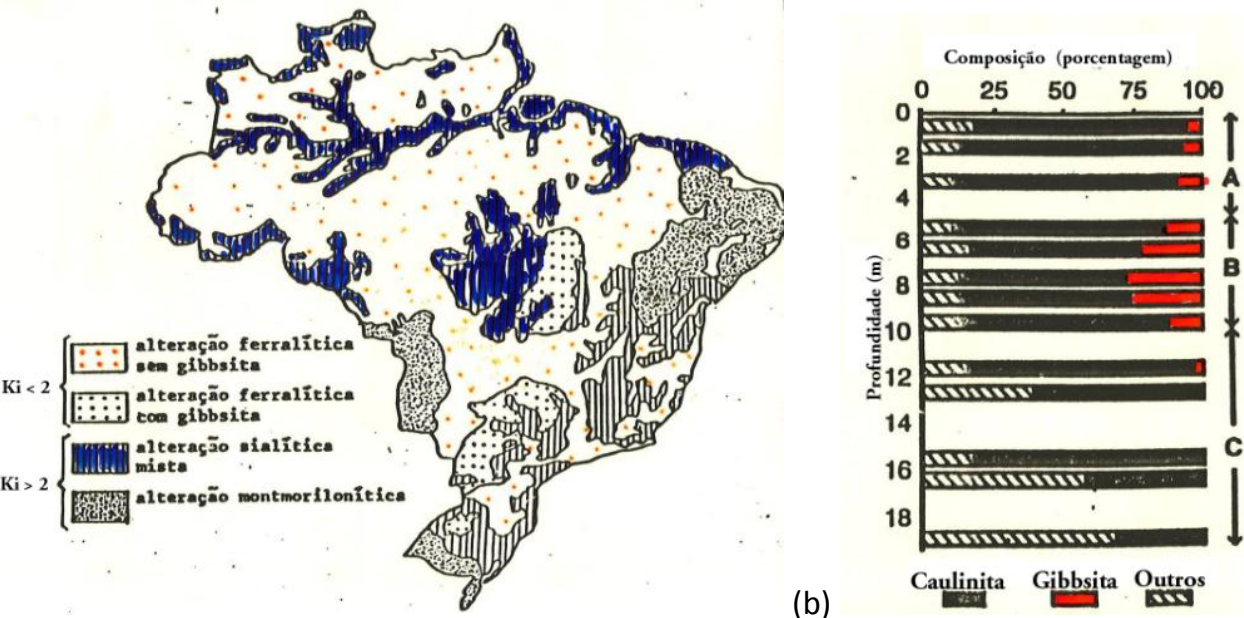

Figura 7. (a) Extensão das principais coberturas de alteração do Brasil (Melfi; Pedro, 1977) e (b) Composição mineralógica dos solos, Latossolos Amarelos, Amazônia, (Lucas et al., 1993). (A) Horizonte argiloso superficial, (B) Horizonte nodular e (C) Alterita.

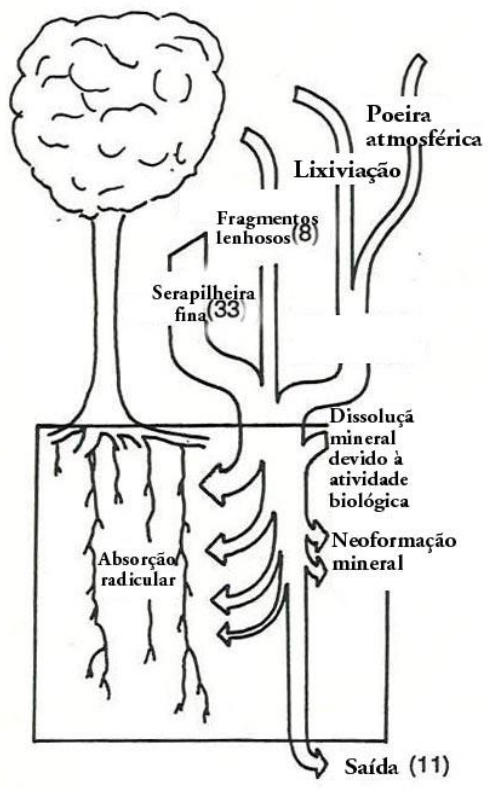

Figura 8. Ciclagem do silício na floresta equatorial, AM (Lucas et al., 1993).

Como explicar o fenômeno? Yves Lucas et al. (1993) explicou da seguinte maneira (fig. 8): A floresta equatorial controla o equilíbrio mineralógico dos solos. A floresta é uma "bomba de silício". O processo de dissolução da caulinita e a neoformação de gibbsita ocorrem:

$$
\begin{aligned}
& \checkmark \text { Caulinita + Água (dissolução) } \rightarrow \text { Gibbsita (ppt) + Ácido Silícico (Sção } \downarrow \text { ) } \\
& \checkmark \mathrm{Si}_{2} \mathrm{O}_{5} \mathrm{Al}_{2}(\mathrm{OH})_{4}+\mathrm{HOH} \rightarrow \mathrm{Al}(\mathrm{OH})_{3}+\mathrm{H}_{4} \mathrm{SiO}_{4}
\end{aligned}
$$

\footnotetext{
${ }^{24}$ Dessaturação em bases e dessilicatização total, onde as temperaturas e pluviometrias são altas e o meio é fortemente drenado.
} 
O silício que deveria partir em solução (sair do sistema), a maior parte, é recapturado pelas raízes das plantas e retornado ao solo, principalmente, pela serapilheira fina (folhas). Com a decomposição da serapilheira, o silício é liberado e recombinado com a gibbsita, de modo a perpetuar o equilíbrio da caulinita em condições equatoriais.

Gabriel Callot (um renomado especialista da relação solo - planta) também teve o "insight" da floresta equatorial como uma "bomba de silício" (comunicação oral). Callot (1992) demonstrou a neoformação de caulinita na epiderme e no córtex de raízes de palmeiras na floresta amazônica (fig. 9).
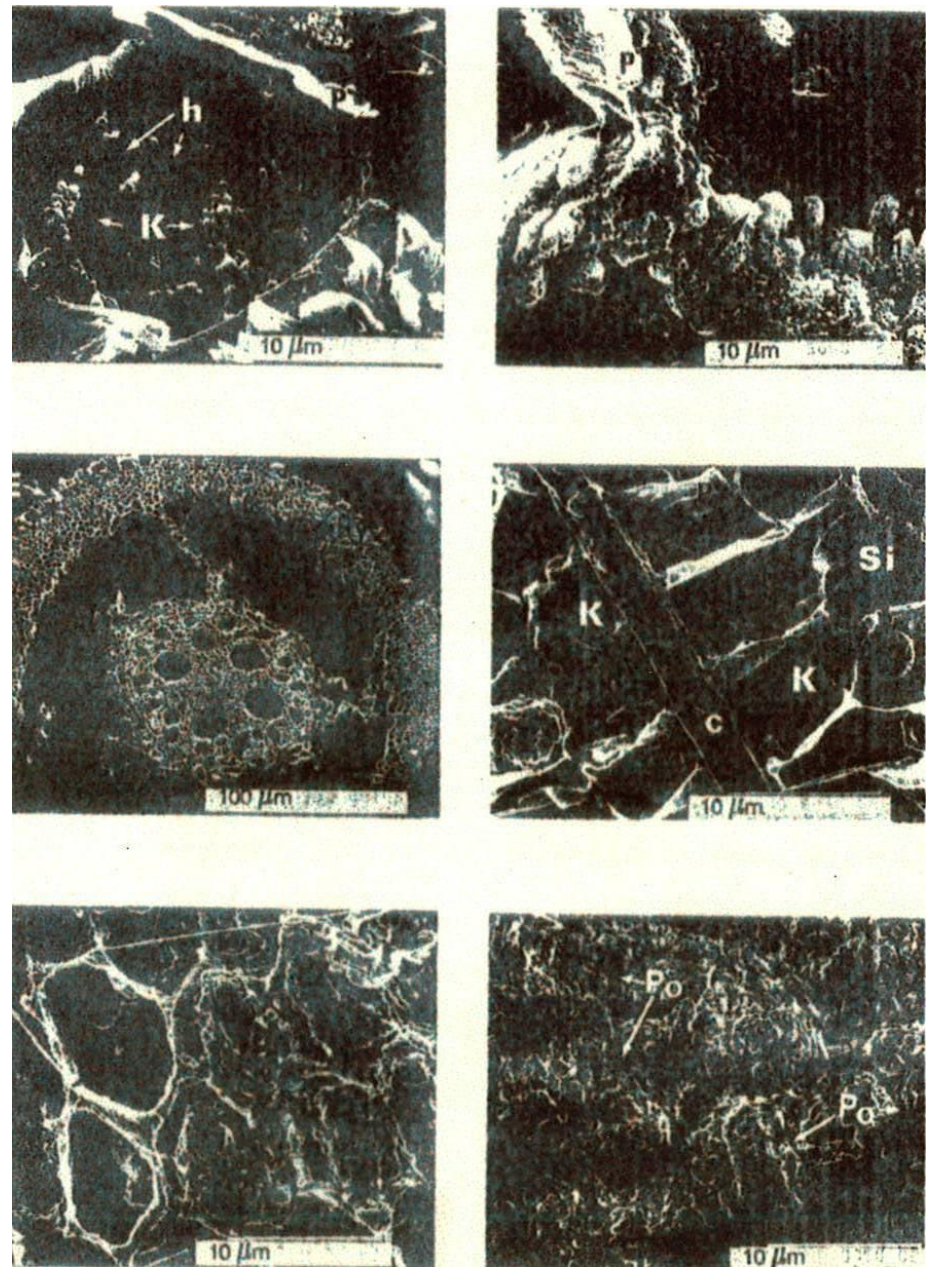

Figura 9. MEV. Concentrações minerais nas células da epiderme e do córtex de raízes de palmeira em floresta equatorial da Amazônia (Callot, 1992). $\mathrm{K}$ = concentrações de caulinita; $\mathrm{Si}$ = concentrações silicosas; $\mathrm{E}=$ epiderme radicular apresentando transformações mineralógicas; $\mathrm{P}=$ paredes celulares; $\mathrm{Po}=$ concentrações argilosas na periferia das raízes com vestígios das paredes celulares.

Seguindo essa linha, foi por acaso que encontrei minerais intrarradiculares em Botucatu, SP. Examinando uma lâmina da camada superficial, arenosa, de um Latossolo Vermelho Amarelo 
Distrófico ${ }^{25}$ do interflúvio da área de pesquisa (Miklós, 1992), deparei-me com cristais de cálcio dentro de raízes. Perguntei-me, como é que determinadas plantas conseguem acumular cálcio em suas raízes sendo o meio tão dessaturado em bases?

(a)

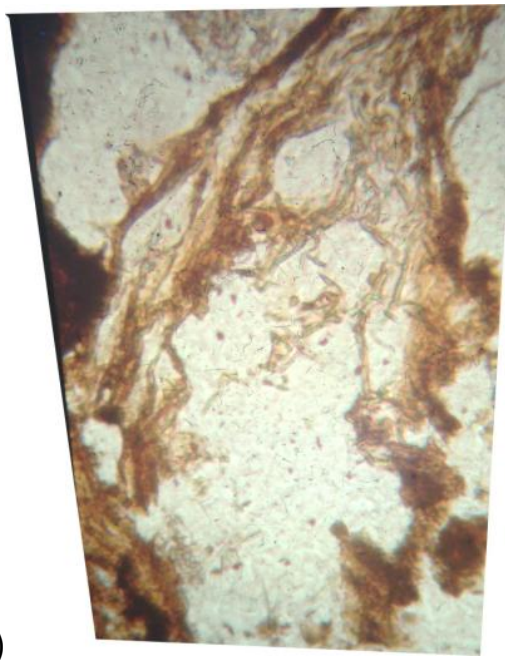

(b)

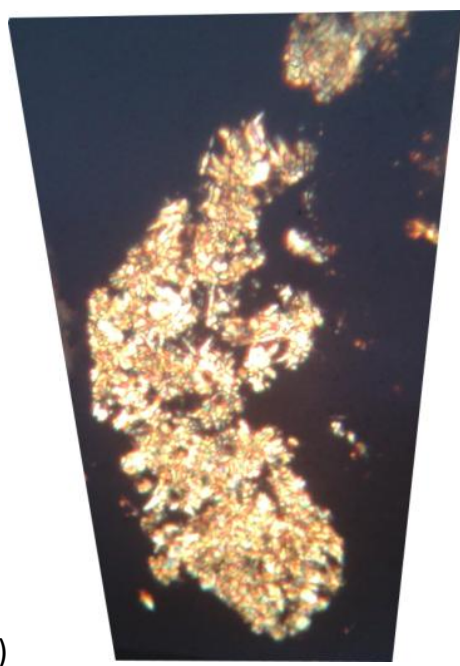

Foto 14. (a) Micrografia sob microscópio ótico e luz transmitida: raiz vegetal com inclusões minerais em horizonte superficial de Latossolo Vermelho Amarelo Distrófico textura média e (b) Micrografia sob microscópio ótico e luz transmitida, polarização cruzada: detalhe dos cristais intrarradiculares, de elevada birrefringência: cristalárias de carbonato ou oxalato de cálcio. [Fotos (a) e (b) A. A. W. Miklós].

Foi também da equipe de Gabriel Callot que saíram trabalhos mostrando o papel das raízes das plantas sobre a granulometria e mineralogia do solo: (a) sobre a neoformação de calcita em raízes de plantas e sua forte contribuição na fração areia de solos mediterrânicos (Jaillard, 1983 e 1984) e, outro, (b) sobre da transformação de micas (flogopita) em vermiculita (Hinsinger, 1990) pela ação de raízes na absorção iônica de potássio interfoliar (figura 10).

A aptidão das raízes das plantas na absorção do potássio interfoliar de micas primárias sempre foi negligenciado no ensino da fertilidade do solo nas escolas de agronomia. $\mathrm{Na}$ realidade, existe um interesse corporativo na manutenção da miopia sobre a disponibilidade do potássio às plantas. Esse conceito leva o agricultor a desconsiderar o compartimento do potássio total no solo $^{26}$, disponível para suas culturas, obrigando-o a comprar potássio solúvel, mesmo quando desnecessário ${ }^{27}$.

\footnotetext{
${ }^{25}$ Dessaturado em bases $\left(\mathrm{Ca}^{+2}, \mathrm{Mg}^{+2}, \mathrm{~K}^{+}\right)$.

${ }^{26}$ Mensurável através da análise de $\mathrm{K}_{2} \mathrm{O}$ total por ataque sulfúrico.

${ }^{27}$ Quando na análise de solo para fins de fertilidade, o K ${ }^{+}$trocável aparece em níveis baixos, mas o solo contém argilas micáceas e/ou micas primárias.
} 


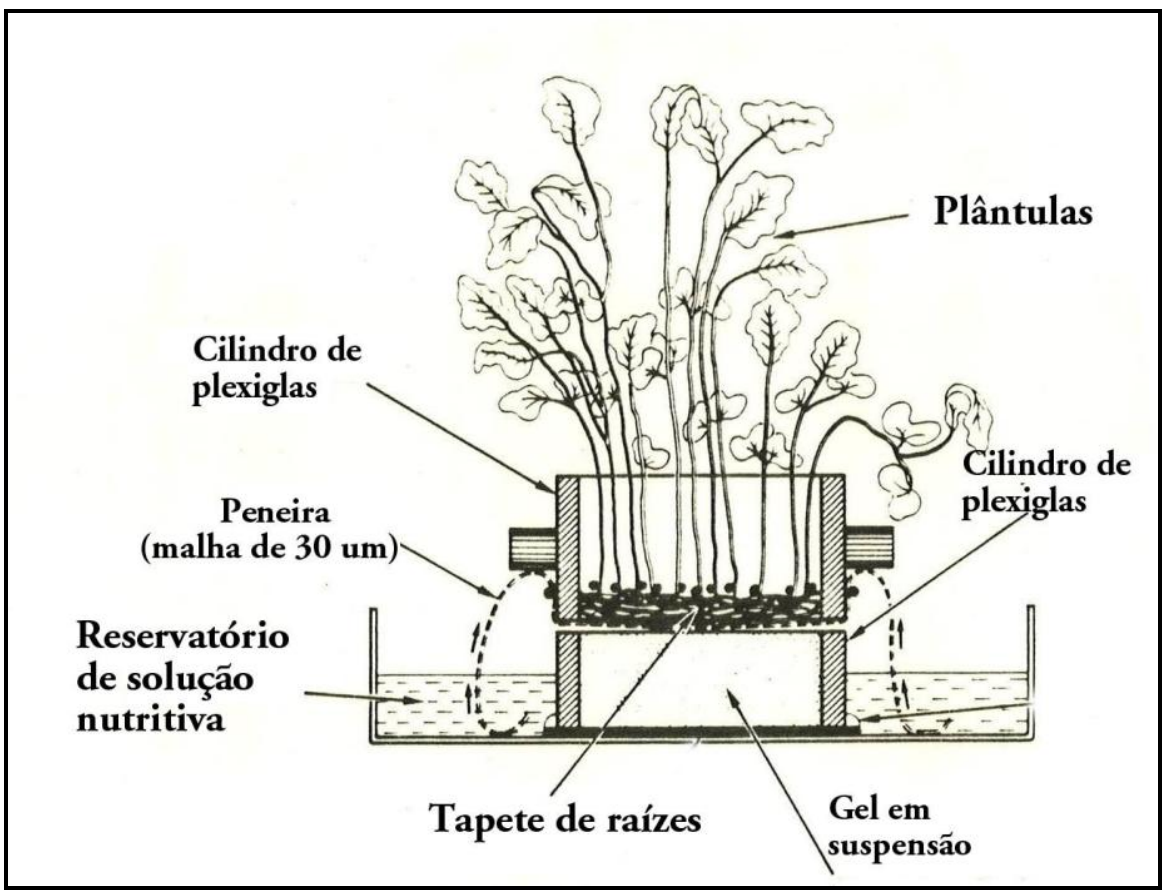

Figura 10. Dispositivo de cultura de raízes sobre géis em suspensão com minerais de referência (micas primárias com potássio interfoliar). A solução nutritiva contém todos os elementos minerais essenciais ao desenvolvimento vegetal com exceção do potássio. As peneiras servem de condutor de nutrientes para as plantas. A peneira impede a colonização do gel em suspensão pelas raízes. (Hinsinger, 1990).

No dispositivo de Hinsinger, análises foliares deram conta da presença de potássio em proporções normais; as plantas, em momento algum deram sinais de deficiência em potássio. Análises mineralógicas com auxílio de raios-X do gel paralelo ao tapete radicular mostraram a transformação da mica primária (10 ̊̊) em Vermiculita (14 ̊̊). Isso ocorreu pela retirada do potássio interfoliar da mica primária pela absorção iônica das raízes; trata-se de uma transformação mineralógica.

Por fim, os vegetais não imobilizam minerais $(\mathrm{N}, \mathrm{P}, \mathrm{K}, \mathrm{Ca}, \mathrm{Mg})$ somente na forma molecular em seus tecidos. Mas, árvores intertropicais, principalmente árvores de madeira de lei, apresentam quantidades apreciáveis de cristais intracelulares na madeira. Esse fenômeno é muito pouco estudado. Vasconcellos et al. (1995) observou grãos de sílica em células dos raios e cadeias cristalíferas nas fibras e células do parênquima (fig. 11).

As raízes são responsáveis por alterações de minerais do solo e minerais primários das rochas (foto 15) (Fernandes Barros, 1996) e pela absorção de nutrientes a partir de trocas catiônicas e aniônicas. 


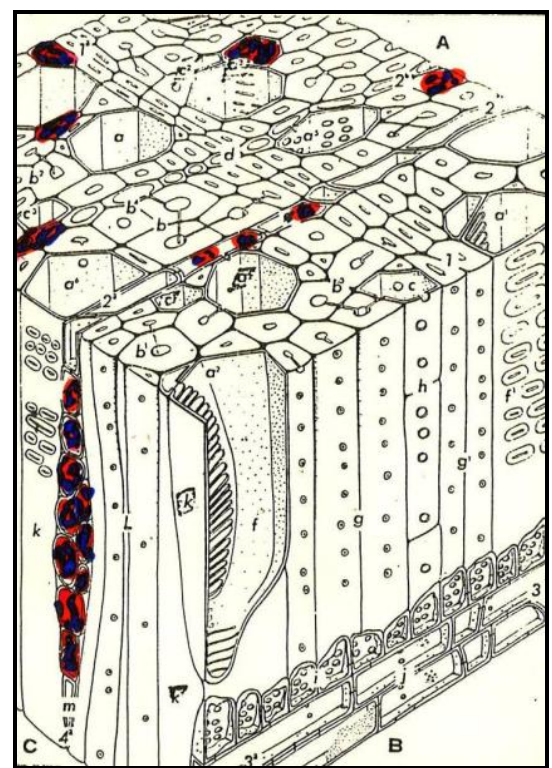

Figura 11. Esquema da estrutura de madeira e da localização dos cristais intracelulares (em cores). $A=$ seç̧ão transversal; $\mathrm{B}=$ secção radial e C = secção tangencial.

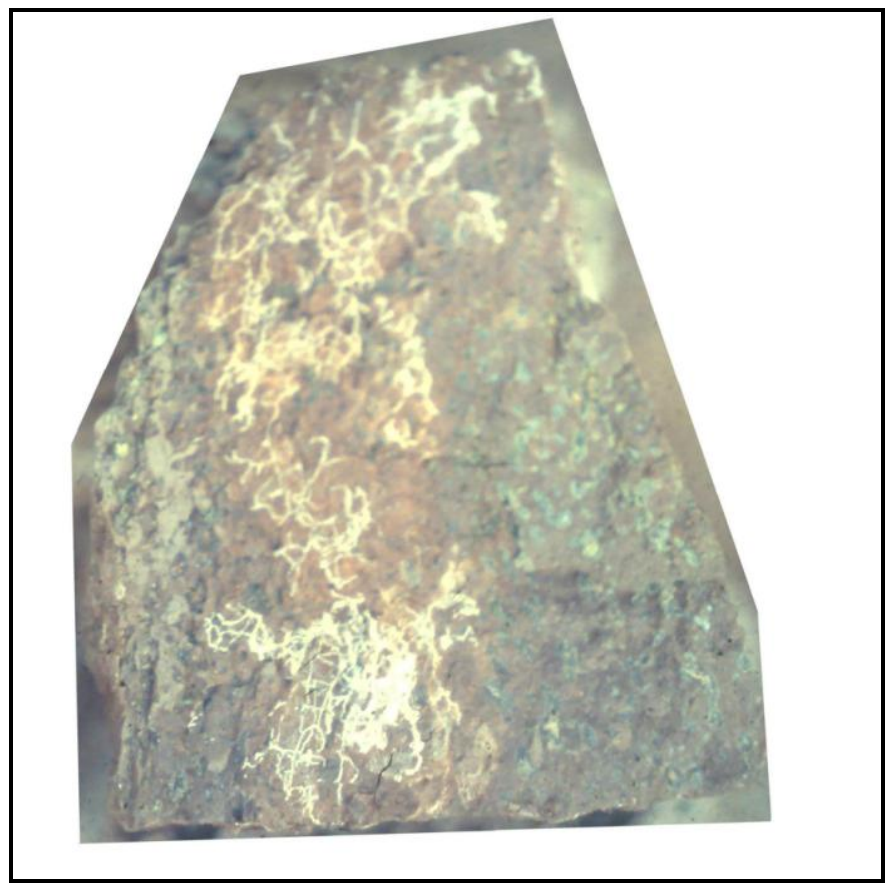

Foto 15. Basalto vesicular alterado pela ação de raízes, Botucatu, SP. Á direita da foto pode-se observar a rocha sã. (Foto A. A. W. Miklós).

O recorde de profundidade de raízes é de 120 m (Callot, com, or.) As raízes são os principais responsáveis pela formação da porosidade do solo (80\%).

\section{Biodiversidade, renovação das terras e cultura agrícola.}

A biodiversidade tem papel regulador insubstituível na renovação das terras. Esse papel depende da cultura agrícola. A renovação do solo depende do papel dos seres vivos na 
organização e dinâmica da paisagem. O solo é um meio renovável? A renovação depende dos balanços físicos de ganhos, a partir da alteração das rochas, e perdas, através das erosões biogeoquímica e mecânica. Mostramos, acima, taxas de "turn-over biológico" (cupins e formigas) variando entre 20 e 400 ton ha $^{-1}$ ano $^{-1}\left(0,2\right.$ a $_{4} \mathrm{~cm}$ ano-1 $)$. Evidentemente, vários outros fatores atuam na formação do solo (clima, relevo, geologia, tempo, organismos). Mas, em clima intertropical, os fatores biológicos superam os abióticos. Se bem que, a microestrutura dos Andossolos e dos Solos Brunos Ácidos da França foi dada como resultado da ação de enquitrídeos (Fitzpatrick, com. or.).

Em contraposição, por conta da agricultura industrial, as perdas de solo podem chegar até 120 ton ha $^{-1}$ ano $^{-1}$. Essas taxas de perda são muito maiores que a taxa média de formação através dos processos físico-químicos naturais $\left(2,6\right.$ ton $\left.\mathrm{ha}^{-1} \mathrm{ano}^{-1}\right)$. Evidentemente, elas não levam em consideração o fator biológico de formação de solo. A visão mecanicista da ciência do solo impediu uma nova forma de ver a renovação de um dos principais elementos essenciais à vida, de um lado. De outro, forneceu a base para o desenvolvimento do sistema agrícola biocida. O balanço é extremamente negativo ao se excluir a biodiversidade como agente formador de solo.

A síntese: a polaridade associação x dissociação como fenômeno vital global.

Na figura 12 observam-se duas polaridades fenomenológicas em escala intertropical:

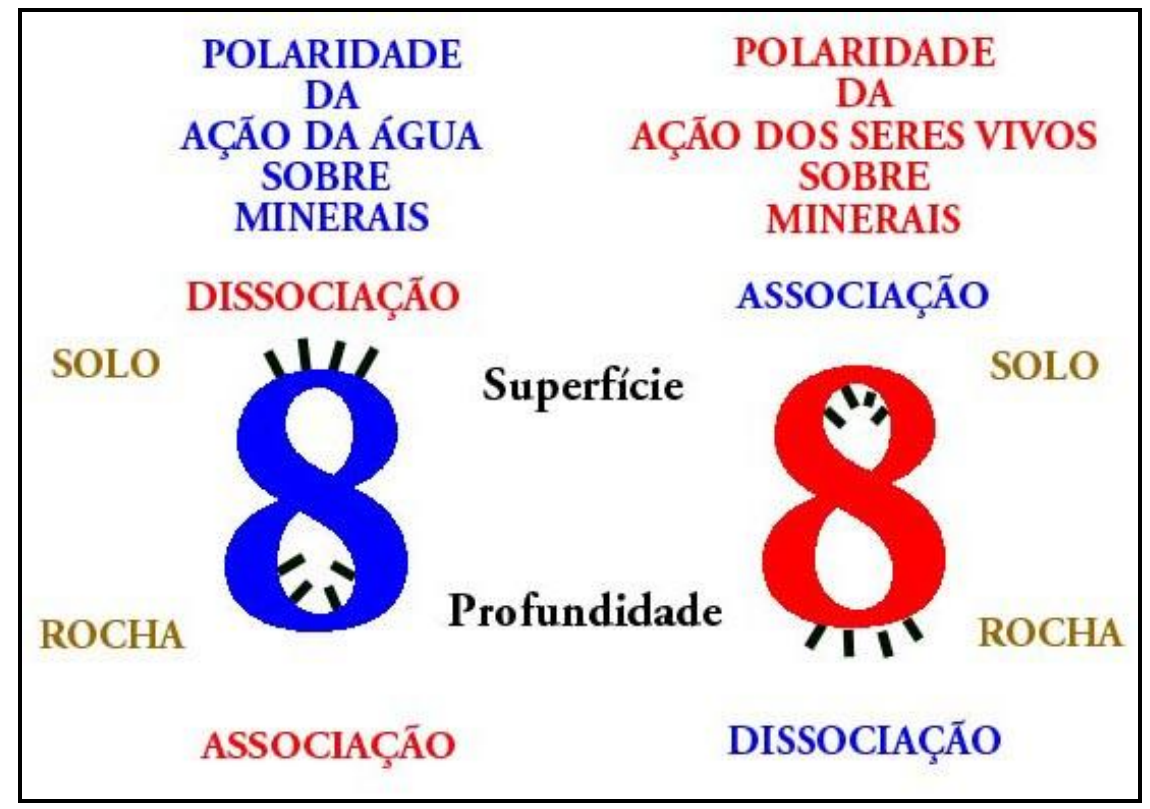

Figura 12. Polaridade da ação da água e dos seres vivos sobre o reino mineral. 
Primeira; da ação da água sobre os minerais em superfície num pólo e em profundidade, no outro.

$\checkmark$ Em superfície, predominam processos dissociativos: as erosões mecânica e geoquímica (dissolução) são os principais exemplos (foto 16). Exemplos radicais são as voçorocas gigantes e o aplainamento generalizado do relevo em decorrência da transformação de latossolos em areias quartzosas, em podzóis hidromórficos no alto Rio Negro. Mesmo sem erosão mecânica a superfície topográfica continental rebaixa continuamente devido à erosão geoquímica.

$\checkmark$ Em profundidade, predominam processos associativos: a argilo-gênese ou neoformação de argilo-minerais é o principal exemplo. Os minerais primários se dissolvem, mas, imediatamente, ao lado, os elementos químicos se reassociam e se hidratam dando origem às argilas.

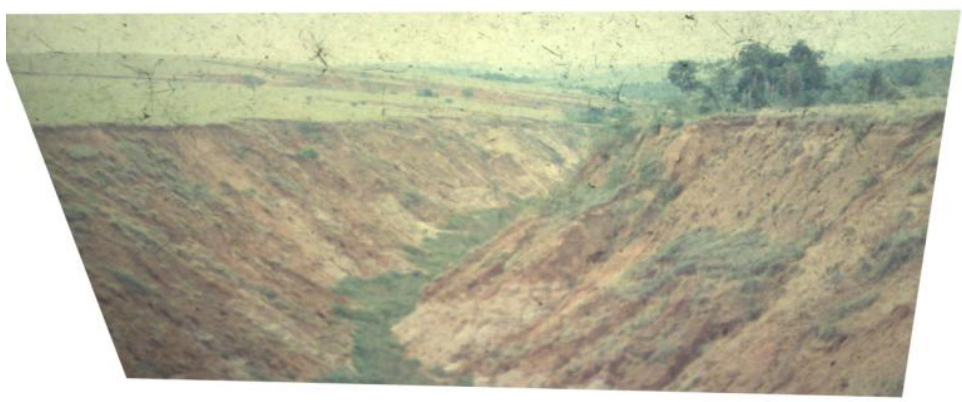

(a)

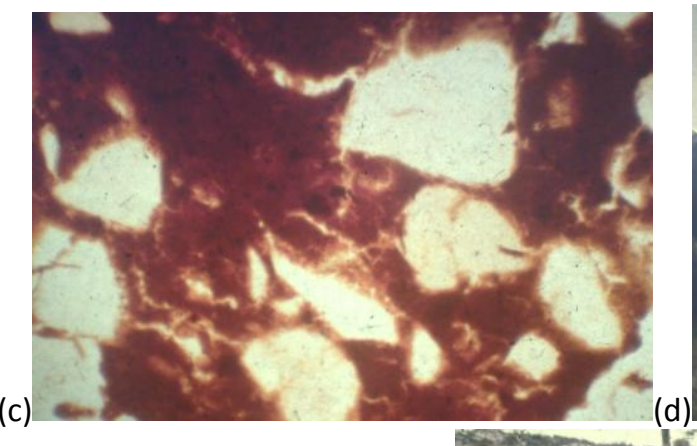

(b)
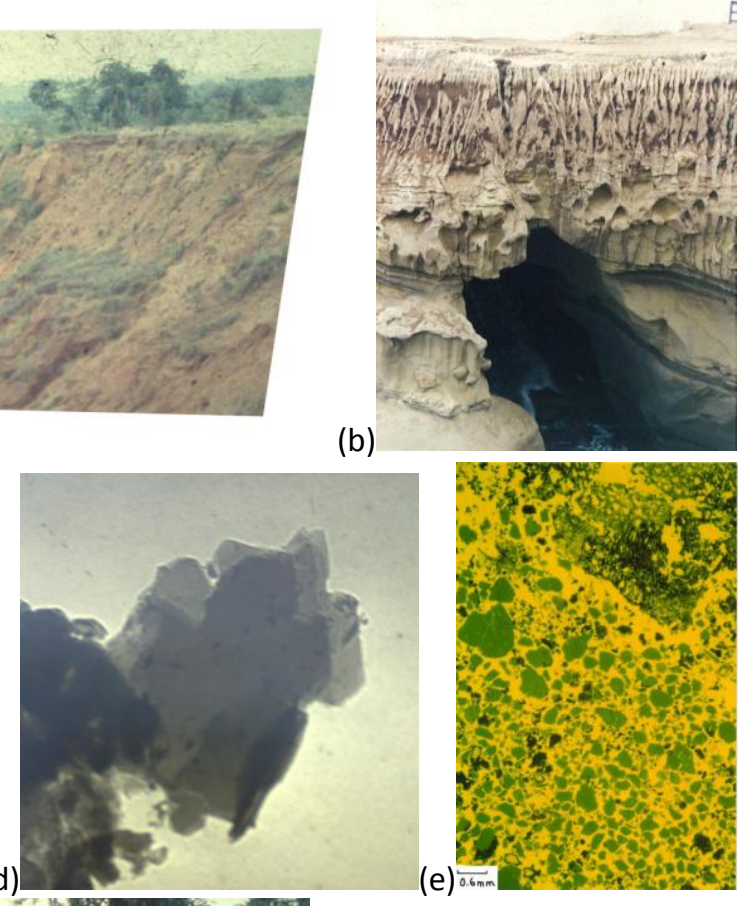

(f)

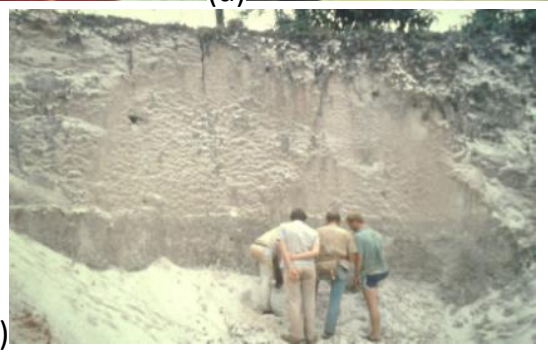

Foto 16. (a) Voçoroca com $30 \mathrm{~m}$ de profundidade e vários quilômetros de extensão, Anhembi, SP; (b) Figuras de dissolução na parte superficial de uma rocha calcária (Mediterrâneo); (c) Micrografia de lâmina delgada sob microscopia ótica e luz transmitida. Figuras de dissolução do plasma (Miklós, 1992); (d) Microscopia Eletrônica 
de Transmissão. Figuras de corrosão nos bordos de cristalitos de caulinita; o eixo maior tem comprimento inferior a 0,1 $\mu \mathrm{m}$ (Miklós, 1986); (e) Lâmina delgada impregnada com pigmento fluorescente sob microscópio ótico e luz ultravioleta. Camada superficial composta por areia lavada sob a serapilheira em um Latossolo Vermelho Amarelo textura média ${ }^{28}$ e (f) Podzol gigante decorrente da transformação de Latossolos Amarelos, Guiana Francesa. [Fotos (a), (c) (d) e (e) A. A. W. Miklós; Foto (b) Flávia Garcia e Foto (f) A. Ruellan).

$\checkmark$ Segunda; da ação dos animais e vegetais sobre o reino mineral, em superfície num pólo e em profundidade noutro.

$\checkmark$ Em superfície, predominam os processos associativos. Os coprólitos e montículos das minhocas, os agregados ovais de formigas e cupins, os termiteiros epígenos, os montículos das saúvas, o "turn-over" biológico, a agregação decorrente da liberação de exudatos de raízes (foto 17), a biogênese de caulinita, de cristais intracelulares em madeira e as sucessões vegetativas conduzidas pelos animais são os exemplos.

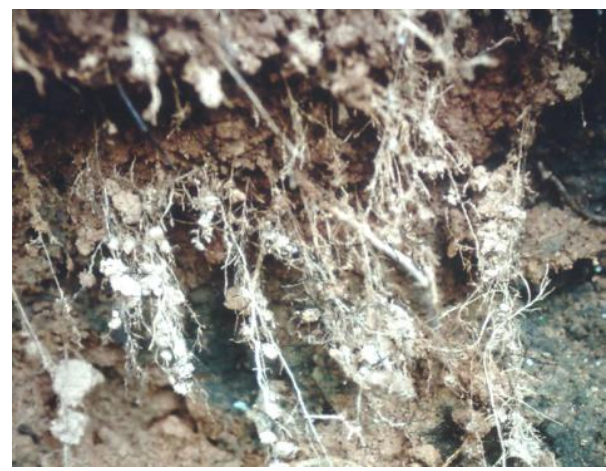

Foto 17. Agregados formados na periferia das raízes pela ação de exudatos radiculares, ricos em polissacarídeos (agentes promotores de agregação).

Em profundidade, predominam os processos dissociativos: a perfuração das raízes, os canais e câmaras da fauna do solo (foto 18), a biodiversidade que escava e decompõe a rocha, o "turn-over" biológico.

\footnotetext{
${ }^{28}$ Os três primeiros centímetros de solo, logo abaixo da serapilheira, são constituídos por areia lavada, decorrente do processo de dissolução das argilas.
} 


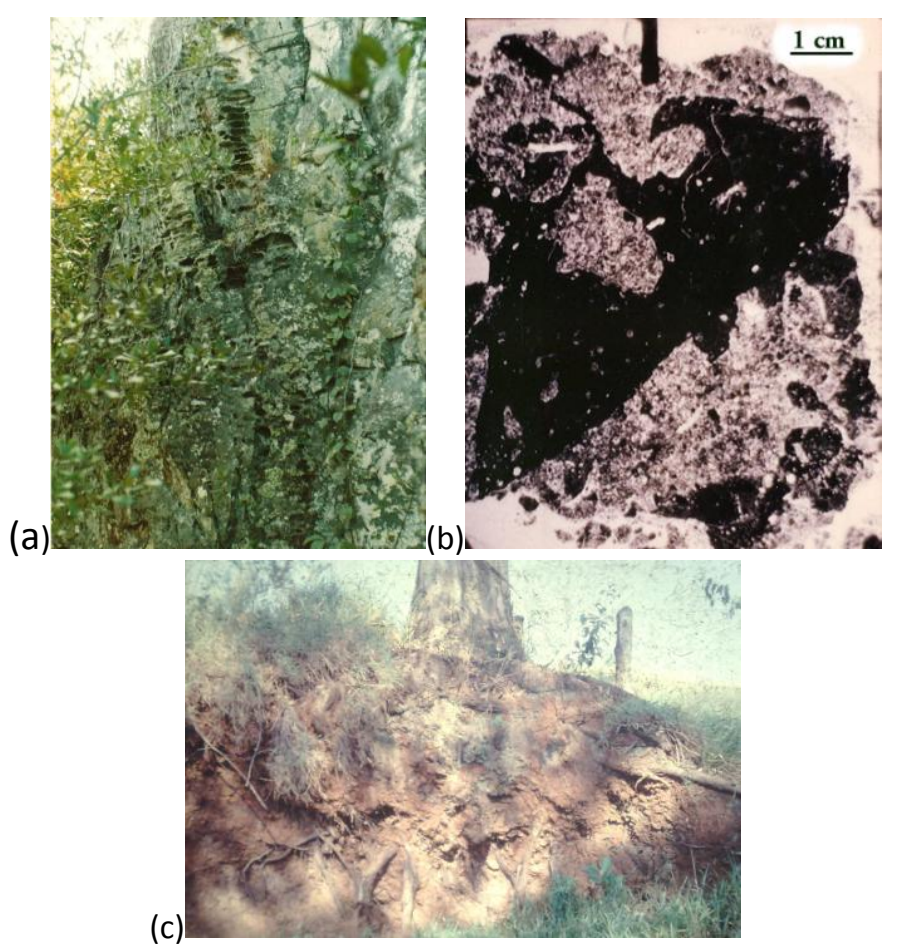

Foto 18. (a) Câmaras de cupins em quartzito da Serra do Espinhaço, MG; (b) Bloco impregnado com resina fluorescente sob luz ultravioleta. Horizonte $\mathrm{C}$ de Latossolo Vermelho (Latossolo Roxo). Plaqueta de isalterita de basalto atravessada por canais de cupins (Miklós, 1992). Lepage (com. or.), no Senegal, encontrou canais de cupins até $50 \mathrm{~m}$ de profundidade e (c) Raízes de Eucalipto perfurando e desagregando uma alterita de basalto em topo de Cuesta Basáltica, Botucatu, SP. [Fotos (a), (b) e (c) A. A. W. Miklós]

Goethe assinalou tal polaridade da mesma forma acima descrita: a polaridade associação "versus" dissociação como fenômeno vital global" ${ }^{29}$. Aristóteles formulou-a, "tudo nasce e morre por construção e desconstrução". Poder-se-ia dizer, ainda, expansão "versus" contração.

Ao analisarmos as polaridades lado a lado, ressaltar-se-ia:

$\checkmark$ Os seres vivos associam lá onde a água dissocia, em superfície,

$\checkmark$ E os organismos vivos dissociam lá onde a água associa, em profundidade.

Em outras palavras, cupins, formigas e outros mais, coletam argila lá onde ela se forma, em profundidade, e a deposita lá onde ela se destrói, em superfície. Eles contrabalançam o empobrecimento superficial do solo imposto pela "lavagem" das chuvas. Savoir-faire?

\section{REFERÊNCIAS BIBLIOGRÁFICAS}

AB'SABER, A. N. Formações quaternárias em áreas de reverso de cuestas em São Paulo. Geomorfologia, Instituto de Geografia, USP, n¹6, 1969, 11p.

\footnotetext{
${ }^{29}$ Fotossíntese e Respiração, também, compõem uma polaridade goethiana, aristotélica; assim por diante...
} 
BACHELEIR, G. La faune dês sols. Son écologie et son action. ORSTOM, INIT. Doc. Tech. $n^{\circ} 38$, 1978, 391p.

BERNARDES, F. F.; MIKLÓS, A. A. W. Comportamento reprodutor, produção de coprólitos e densidade populacional de Pontoscolex corethrurus (minhoca mansa). In: Simpósio de Iniciação Científica da Universidade de São Paulo, , Piracicaba: ESALQ / USP, v.2, 1994, pp. k5-k5.

BOISSEZON, P.; MOUREAUX, C.; BOQUEL, G.; BACHELIER, G. Les sols ferrallitiques. Tome IV. La matière organique et la vie dans les sols ferrallitiques. ORSTOM, INIT. Doc. Tech., $n^{\circ} 21$, $1973,146 p$.

BOULET, R.; CHAUVEL, A.; HUMBEL, F. X.; LUCAS Y. Analyse structurale et cartographie en pédologie. Cah. ORSTOM, sér. Péd., n 4, v.19, 1982, pp.309-321.

BOULET, R.; PESSENDA, L. C. R. ; TELLES, E. C. C.; MELFI, A. J. Une évaluation de la vitesse de l'accumulation de matière par la faune du sol à partir de la datation des charbons de bois e d'humine du sol. Exemple des Latosols des versants du lac Campestre, Salitre, Minas Gerais, Brésil. CRAS, Sér. IIA, v.27, 1995, pp.287-294.

BULLETIN OF THE INTERNATIONAL UNION OF SOIL SCIENCE, n4, 1993.

CALlot, G; CHAUVEL, A.; ARVIEU, J. C.; CHAMAYOU, H. Mise en évidence de kaolinite et de silice dans les structures cellulaires de l'épiderme et du cortex des racines de palmier, en Forêt d'Amazonie. Bull. Soc. bot. Fr., 139, Actual. bot., 1992, pp.7-14.

ESCHENBRENNER, V. Contribution des termites à la microagrégation des sols tropicaux. Cah. ORSTOM, sér. Péd., vol. 22, n4, 1986, pp.397-408.

ESPINDOLA, C. R. Retrospectiva crítica sobre a pedologia. Campinas, SP, Ed. UNICAMP, 2008, $397 p$.

FERNANDES BARROS, O. N. Formação de horizontes pedológicos sobre basalto (Londrina, PR) e ação biológica no intemperismo. Tese de Doutorado, Departamento de Geografia, USP, 1996. 
FONTES, L. R.; BERTI FILHO, E. Cupins. O desafio do conhecimento. Piracicaba: FEALQ, 1998, $512 p$.

GRAMINHA, C. A.; MELFI A. J. Contribuição dos cupins na formação de solos tropicai8s: estudo de perfis de alteração basalto - latossolo no estado de São Paulo. Acta Geológica Leopoldensia, v.52/53, 2001, pp.385-390.

HINSINGER, P. Action dês racines sur La liberation Du potassium et l'altération de minéraux silicatés. Thèse de Doctorat, ENSAM, Montpellier, 1990, 185p.

HOLE, F. D. Effects of animals on soil. Geoderma, v.25, 1981, pp.75-112.

JAILLARD, B. Mise en evidence de la néogenèse de sables calcaires sous l'influence des racines: incidence sur la granulometrie du sol. Agronomie, 4, 1984, pp91-100.

JAILLARD, B. Mise en évidence de la calcitisation des cellules corticales de racines de graminées em milieu carbonaté. C. R. Acad. Sci. Paris. t.297, Sér.II, 1983, pp. 293-296.

JONKMAN, J. C. M. The external and internal structure and growth of nests of leaf-cutting ant Atta vollenweideri Forel, 1983 (Hym.: Formicidae). Part II. 4. The internal nest and growth. Zeitschrift für angewanddte Entomologie. Sonderdruck aus Bd. 89, H.3, 1980, pp.217-246.

JONKMAN, J. C. M. Nests of leaf-cutting ant Atta volenweideri as accelerators of succession in pastures. Zeitschrift für angewanddte Entomologie. Sonderdruck aus Bd.86, H.1, 1978, pp.25-34.

LEE, K. E.; WOOD, T. G. Termites and soils. Academic Press, London, 1971, 251p.

LUCAS, Y.; LUIZÃO, F. J.; CHAUVEL, A.; ROUILLER, J.; NAHON, D. The relation between biological activity of the rain forest and mineral composition of soils. Science, v.260, 1993, pp.521-523.

MAFRA, A. L.; MIKLÓS, A. A. W.; VOLKOF, B.; MELFI, A. J. Pedogênese numa sequência Latossolo - Espodossolo na região do alto Rio Negro. R. Bras. Ci. Solo, vol. 26, n², 2002, pp.381-394. 
MAFRA A. L.; MIKLÓS, A. A. W.; MELFI, A. J.; ESCHENBRENNER, V.; VOLKOF, B. Ação das minhocas na estrutura e composição química de um solo arenoso hidromórfico do Amazonas. In: Minhocas na América Latina: Biodiversidade e ecologia. 1a Ed. Londrina: EMBRAPA Soja, v.1, 2007, pp.407-419.

MELFI, A. J.; PEDRO, G. Estudo geoquímico dos solos e formações superficiais do Brasil. 1. Caracterização e repartição dos principais tipos de evolução pedogeoquímica. R. Bras. Geoc., v.7, 1977, pp 271-286.

MIKLÓS, A. A. W. Relations entre l'altération et la pédogenèse danas un profil vertical sur basalte de la région de Botucatu, Brésil. Dip. d’Et. Aprof., Lab. Ped., Petr. Met. Surf., Université de Poitiers, 1986, 45p.

MIKLÓS, A. A. W. Biodynamique d’une couverture pédologique dans La région de Botucatu (Brésil - SP). Thèse de Doctorat de l'Univérsité Paris VI, v.1, v.2 1992, 247p.

MIKLÓS, A. A. W. Contribution to knowledge on soil formation rates. A case study: the pedological cover of Botucatu. In: $16^{\text {th }}$ World Congress of Soil Science. v.1, 1998, pp.381-381. MOUSINHO, M. R.; BIGARELLA, J. J. Movimentos de massa no transporte de detritos da meteorização das rochas. Bol. Paran. Geogr., Curitiba, 16/17, 1969, pp.43-84.

PENTEADO, M. M. Geomorfologia do setor centro-ocidental da depressão periférica paulista. Tese de Doutorado, Instituto de Geografia, USP, n²2, 1976, 85p.

PESSENDA, L. C. R.; VelenCiA, E. P. E.; CAMARGO, P. B.; TELLES, E. C. C.; MARTINELLI, L. A.; CERRI, C. C.; ARAVENA, R.; ROZANSKI, K. Natural radiocarbon measurements in brazilian soil developed on basic rocks. Radiocarbon, New Haven, v.38, n², 1996, pp.203-208.

QUEIROZ NETO J. P.; CASTRO, S. S.; BOULET, R.; NICOLA, S. N.; MIKLÓS, A. A. W.; FERNANDES BARROS, O. N. Análise estrutural da cobertura pedológica. Guia de Excursão. XXI Congresso Brasileiro de Ciência do Solo. Campinas, 1987.

RUELLAN, A. Les apports de la connaissance des sols intertropicaux et dévéloppment de la pédologie - Contribution des pédologues français. Catena, v.12, 1985, pp.87-98. 
SCHAEFER, C. E. R. The microstructure of latosols as a long-term pedobiological construct. $16^{\text {th }}$ World Congress of Soil Science. Montpellier, France, v.1, 1998, pp. 381-381.

SERRES, M. Luzes - Cinco estre4vistas com Bruno Latour. Ed. Unimarco, 1999, 272p.

STEINER, R. Goethe et as conception du Monde. Ed. Anthroposophiques Romandes, GA n6,

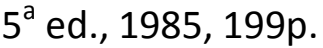

VASCONCELOS, F. J.; FREITAS, J. A.; SILVA, A. C. Observação microscópica de inclusões minerais no xilema de espécies tropicais da Amazônia. Acta Amazônica, v.25, n¹/2, 1995, pp.55-68. 